\title{
Learning Demonstration Interim Progress Report - Summer 2007
}

Technical Report NREL/TP-560-41848 July 2007
K. Wipke, S. Sprik, H. Thomas, C. Welch, and J. Kurtz 


\section{Learning Demonstration Interim Progress Report - Summer 2007}

Technical Report NREL/TP-560-41848 July 2007

\author{
K. Wipke, S. Sprik, H. Thomas, C. Welch, and \\ J. Kurtz
}

Prepared under Task No. H270.8100

National Renewable Energy Laboratory

1617 Cole Boulevard, Golden, Colorado 80401-3393

303-275-3000 • www.nrel.gov

Operated for the U.S. Department of Energy

Office of Energy Efficiency and Renewable Energy

by Midwest Research Institute • Battelle

Contract No. DE-AC36-99-G010337

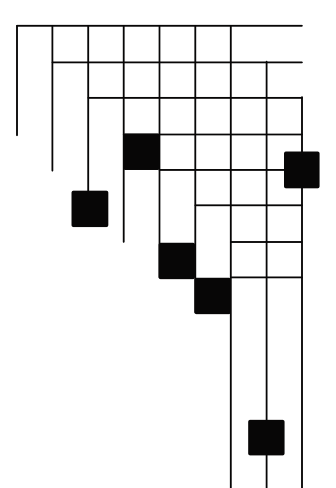




\section{NOTICE}

This report was prepared as an account of work sponsored by an agency of the United States government. Neither the United States government nor any agency thereof, nor any of their employees, makes any warranty, express or implied, or assumes any legal liability or responsibility for the accuracy, completeness, or usefulness of any information, apparatus, product, or process disclosed, or represents that its use would not infringe privately owned rights. Reference herein to any specific commercial product, process, or service by trade name, trademark, manufacturer, or otherwise does not necessarily constitute or imply its endorsement, recommendation, or favoring by the United States government or any agency thereof. The views and opinions of authors expressed herein do not necessarily state or reflect those of the United States government or any agency thereof.

Available electronically at http://www.osti.gov/bridge

Available for a processing fee to U.S. Department of Energy and its contractors, in paper, from:

U.S. Department of Energy

Office of Scientific and Technical Information

P.O. Box 62

Oak Ridge, TN 37831-0062

phone: 865.576 .8401

fax: 865.576 .5728

email: mailto:reports@adonis.osti.gov

Available for sale to the public, in paper, from:

U.S. Department of Commerce

National Technical Information Service

5285 Port Royal Road

Springfield, VA 22161

phone: 800.553.6847

fax: 703.605.6900

email: orders@ntis.fedworld.gov

online ordering: http://www.ntis.gov/ordering.htm 


\section{Learning Demonstration Interim Progress Report - Summer 2007}

\subsection{Introduction}

This purpose of this report is to document and discuss key results to date from the U.S. Department of Energy's (DOE) Controlled Hydrogen Fleet and Infrastructure Validation and Demonstration Project, also referred to as the fuel cell vehicle learning demonstration. This report serves as one of many mechanisms to help transfer knowledge and lessons learned within various parts of DOE's hydrogen program, as well as externally to other stakeholders. Other mechanisms have included: briefings to FreedomCAR technical teams (five in the last year), presentations at technical conferences (National Hydrogen Association, Fuel Cell Seminar, and EVS-22 conferences), postings of individual results to the National Renewable Energy Laboratory's (NREL) Web site, presentations at DOE's Annual Merit Review, and participation in groups such as the California Hydrogen Business Council, US Fuel Cell Council Joint Hydrogen Quality Task Force, and various California Fuel Cell Partnership working groups.

The primary goal of this project is to validate vehicle/infrastructure systems using hydrogen as a transportation fuel for light-duty vehicles. This means validating the use of fuel cell vehicles (FCVs) and hydrogen refueling infrastructure under real-world conditions using multiple sites, varying climates, and a variety of sources for hydrogen. See Figure 1 for photographs of the first-generation vehicles and logos of the four teams and Figure 2 for photographs representing the four types of hydrogen refueling stations.
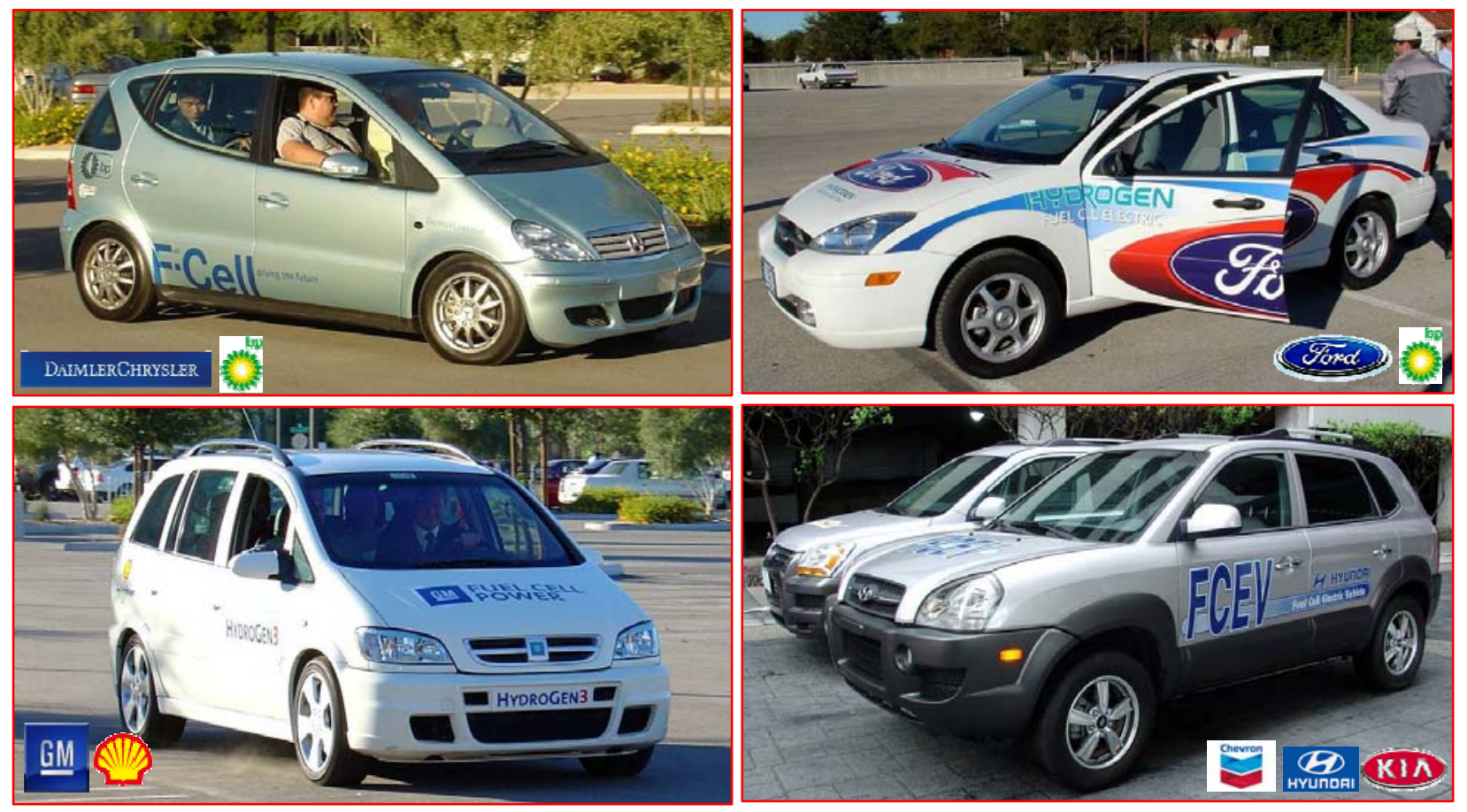

Figure 1: Photographs of the Four Teams' First-Generation Vehicles 


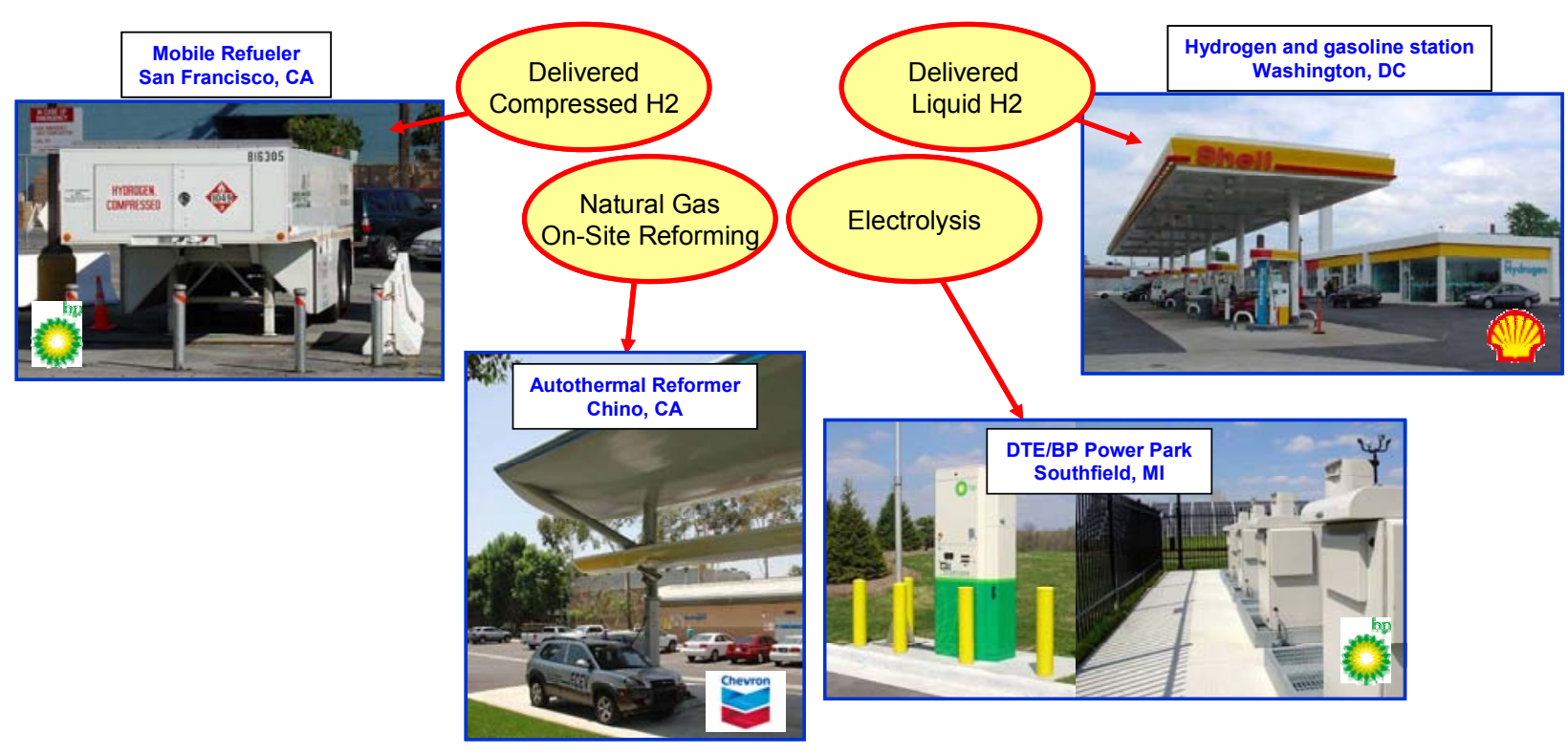

Figure 2: Four Types of Hydrogen Production and Refueling Facilities with Examples

By 2009 we will validate hydrogen vehicles with greater than 250-mile range, 2,000-hour fuel cell durability, and \$3/gge hydrogen production cost (based on volume production). We are identifying the current status of the technology and tracking its evolution over the five-year project duration, particularly between the first- and second-generation FCVs. NREL's role in this project is to provide maximum value for DOE and industry from the data produced by this "learning demonstration." We seek to gain knowledge about the progress toward the technical targets, and provide that data to the HFCIT R\&D activities. This information allows the program to move more quickly toward cost-effective, reliable hydrogen FCVs and supporting refueling infrastructure.

\subsection{Approach}

NREL's approach to accomplishing the project's objectives is structured around a highly collaborative relationship with each of the four industry teams, including Chevron/Hyundai-Kia, DaimlerChrysler/BP, Ford/BP, and GM/Shell. We are receiving raw technical data from both the hydrogen vehicles and refueling infrastructure that allows us to perform unique and valuable analyses across all four teams. Our primary objectives are to feed the current technical challenges and opportunities back into the DOE Hydrogen R\&D Program and assess the current status and progress toward targets. To protect the commercial value of these data for each company, we established the Hydrogen Secure Data Center (HSDC) to house the data and perform our analysis (Figure 3 shows the flow of data and results). To ensure value is fed back to the hydrogen community, we publish composite data products twice a year at technical conferences. These data products report on the progress of the technology and the project, focusing on the most significant results. Additional composite data products are conceived as additional trends and results of interest are identified. We also provide our detailed analytical results (not public) on each individual company's data back to them to maximize the industry benefit from NREL's analysis work and obtain feedback on our methodologies. 


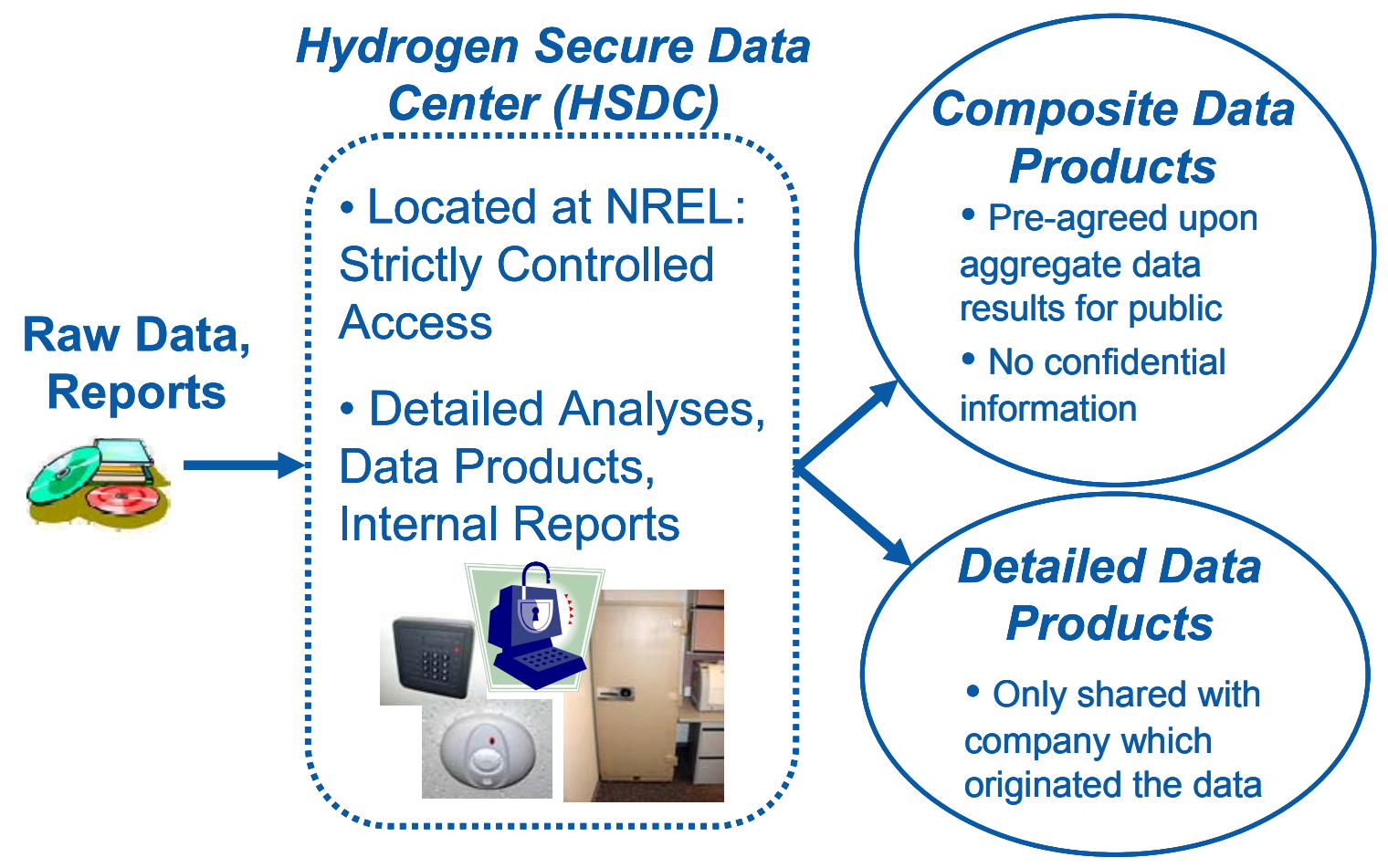

Figure 3: Process Flow for Hydrogen Secure Data Center Analysis and Results

\subsection{Key Analysis Accomplishments in FY 2007}

- Created and published 30 new or updated composite data products (the third such set of public results) representing results from analyzing almost two years of Learning Demonstration data. Presented results publicly at EVS-22, the Fuel Cell Seminar, the National Hydrogen Association conference, and the 2007 DOE Hydrogen Program Merit Review meeting.

- Created a new NREL Web page at http://www.nrel.gov/hydrogen/cdp topic.html to allow direct public access to the latest composite data products, organized by topic, date, and CDP number. This also allowed the results to be indexed directly by search engines.

- Made major improvements to NREL's Fleet Analysis Toolkit (FAT) for automatically processing and analyzing every vehicle trip file and presenting the results graphically in an interactive manner.

- Received and processed a total of 141,000 individual vehicle trips, amounting to over 38 GB of data, since inception of the project.

- Created a new MATLAB analysis program to analyze dominant factors affecting fuel cell degradation, including a new graphical user interface for viewing the results in an interactive way.

- Further developed the collaborative technical relationship with all four industry teams by giving presentations to each team, including detailed results from NREL's analysis of their vehicle and infrastructure data. 


\subsection{Section 1: Vehicle Results}

The results in FY 2007 came from analyzing an additional year of data (January - December 2006), creating a total of 30 new or updated composite data products we presented at three technical conferences. To accomplish this, our in-house analysis tool, the Fleet Analysis Toolkit, underwent significant improvements and revisions. Since there are now so many technical results from the project, they cannot normally all be discussed during brief conference presentations. Therefore, in January 2007 NREL launched a new Web page at http://www.nrel.gov/hydrogen/cdp topic.html to provide the public with direct access to the results. These results have also been presented publicly at the Fuel Cell Seminar (11/06), the EVS-22 conference in Japan (12/06), and the 2007 National Hydrogen Association meeting (3/07) as two distinct sets of results (labeled "Fall 2006" and "Spring 2007"). In order to focus on the high-level results and conclusions, this report will discuss the results in bullet form, organized by topic. The last section includes all of the composite data products referenced.

- Fuel Cell Efficiency: The fuel cell system efficiency was measured from select vehicles on a vehicle chassis dynamometer at several steady-state points of operation. DOE's technical target for net system efficiency at $1 / 4$-power is $60 \%$. Data from the four Learning Demonstration teams showed a range of net system efficiency from $52.5 \%$ to $58.1 \%$ (Figure 4), which is very close to the target. Efficiency of the 2 nd generation systems will be evaluated as soon as they are introduced through baseline testing.

- Vehicle Fuel Economy: Vehicle fuel economy was measured from city and highway drive-cycle tests (Figure 5) on a chassis dynamometer using draft SAE J2572 (left blue bar, representing the range of four points, one from each OEM). These raw test results were then adjusted according to U.S. Environmental Protection Agency (EPA) methods to create the "window-sticker" fuel economy that consumers see when purchasing the vehicles ( $0.78 \times$ Hwy, $0.9 \times$ City) (center blue bar). This resulted in an adjusted fueleconomy range of 42 to 56.5 miles $/ \mathrm{kg}$ hydrogen for the four teams. As with all vehicles sold today, including gasoline hybrids, on-road fuel economy is slightly lower than this rated fuel economy (right blue bar). Note that EPA has adjusted its testing and reporting methodology beginning with model-year 2008 vehicles to try to make the window-sticker fuel economy better reflect on-road driving performance.

- Vehicle Driving Range: Vehicle range was calculated using the fuel economy results discussed above and multiplying them by the usable hydrogen stored onboard each vehicle (Figure 6). Using the EPA-adjusted fuel economy resulted in a range from just over 100 miles up to 190 miles from the four teams. The $2^{\text {nd }}$ generation vehicles will strive to push this range up to 250 miles to reach the 2009 DOE target. Note that two other composite data products relating to range were also generated. Figure 7 shows a histogram of the distance vehicles actually traveled between refuelings as a percentage of each vehicle's dyno range. This shows that the majority of the vehicles $(80 \%)$ travel less than $50 \%$ of the dyno range between refuelings. This is due to several factors, but the dominant ones are limited $\mathrm{H} 2$ infrastructure, fear of running out of fuel, and actual onroad fuel economy being lower than the dynamometer fuel economy, as has already been discussed. Figure 8 shows a large spread of on-road range from the four teams (green bar) as a percentage of their dyno range. 
- Fuel Cell Durability: Fuel cell stacks will need roughly a 5,000 hour life to enter the market for light-duty vehicles. For this demonstration project, targets were set at 1,000 hours in 2006, and 2,000 hours in 2009. By creating periodic fuel cell polarization curve fits using the on-road stack voltage and current data, we calculated the voltage under high current and used it to track the gradual degradation of the stacks with time. We then compared these results to the first-generation target of 1,000 hours for 2006. Since the vehicles have not yet been driven long enough to acquire 1,000 hours of operation (a range of fleet averages from 145 to 379 hours for the four teams, as shown in Figure 9), we extrapolated based on the slope of the voltage degradation $(\mathrm{mV} /$ hour times the $10 \%$ voltage drop target). The projected times to $10 \%$ fuel cell stack voltage degradation from the four teams had an average of over 700 hours with a high projection of over 1,250 hours from one team, straddling the 1,000 hour DOE target (Figure 10). Note that this $10 \%$ criterion, which is used for assessing progress toward DOE targets, may differ from the OEM's end-of-life criterion and does not address "catastrophic" failure modes such as membrane failure. The $2^{\text {nd }}$ generation stacks introduced in this project beginning in late 2007 will be compared to the 2,000 hour target for 2009 .

- Vehicle Safety: The Learning Demonstration has had a very strong safety record to date. In accordance with DOE's safety definitions, there have been no safety incidents or near misses involving the vehicles; they have all been non-events. There was one reported issue with properly setting thresholds for triggering onboard alarms from hydrogen sensors that is being resolved by the company involved. This occurred in Quarter 4, 2006, as can be seen in Figure 11 by the spike in the number of safety reports for that quarter. This resolution will also involve a reassessment by that company of the type of safety data reported to the HSDC, and will likely involve an update to the number of reports (lower) for previous and future quarters.

- Other Vehicle Metrics: There have been several other vehicle-related composite data products that will be briefly mentioned here. Figure 12 shows the range of ambient temperature during vehicle operation spanning from $3^{\circ} \mathrm{F}-123^{\circ} \mathrm{F}$. So fuel cell vehicles are currently able to operate in extreme temperature conditions, but $2^{\text {nd }}$ generation vehicle tests will determine their ability to also start from sub-freezing temperatures. Figure 13 shows the distribution of vehicle operating hours, showing a median of 300-400 hours. Similarly with vehicle miles traveled (shown in Figure 14), the peak number of vehicles occurs at 6,000-8,000 miles. The total number of vehicle miles traveled through December 2006 is 573,064, and Figure 15 shows that after the first few quarters, mileage accumulation has been relatively linear. Figure 16 tracks the total number of Learning Demonstration vehicles deployed by quarter, and the on-board hydrogen storage systems that they use. 


\subsection{Section 2: Infrastructure Results}

- Hydrogen Quality: Hydrogen quality was determined by measuring the impurities and calculating the hydrogen fuel quality index as a percentage. SAE J2719 has established a $99.99 \%$ hydrogen fuel quality index target. The hydrogen fuel quality index from all the stations sampled ranged from $99.73 \%$ to $99.999 \%$, as shown in Figure 17. The values on the lower end were due to some high detection limits on inert gases, and likely do not really represent hydrogen fuel quality that low.

- Hydrogen Impurities: More important than the absolute hydrogen fuel quality index is the actual level of impurities by constituent. Impurities evaluated include particulates, inert gases $\left(\mathrm{N}_{2}+\mathrm{H}_{2}+\mathrm{Ar}\right), \mathrm{NH}_{3}, \mathrm{CO}, \mathrm{CO}_{2}, \mathrm{O}_{2}$, total $\mathrm{HC}, \mathrm{H}_{2} \mathrm{O}$, and total sulfur, and are shown in Figure 18. One key finding was that reported values are, in general, close to the SAE J2719 target values. For total sulfur, we observed that all of the data were reported at the detection limits of the gas analysis hardware used. So while the target for sulfur is 4 parts per billion ( $\mathrm{ppb}$ ), detection-limited results ranged from 3-70 ppb. Therefore, either new cost-effective techniques to get real measurements at such low concentrations should be developed, or the target should be raised to something that can be measured with confidence.

- $\mathrm{H}_{2}$ Infrastructure Maintenance: An evaluation of all of the maintenance required on refueling station equipment found that roughly $1 / 2$ of all labor hours were unplanned, accounting for $60 \%$ of the maintenance events (Figure 19). This reflects the early nature of technology maturity for the stations, and will be tracked as the technology matures and more stations are put into service.

- Infrastructure Safety: With respect to hydrogen refueling infrastructure, there has only been one event that was classified as an incident. It involved a piece of equipment that was incorrectly installed and led to the release of hydrogen from the station's storage tanks into the atmosphere. There were no injuries and no damage except for the piece of equipment involved. At a less severe level (see Figure 20), there were nine events categorized as near-misses and 59 non-events (primarily alarms-only and equipment malfunctions). All but one of the near-misses involved a minor release of hydrogen with no ignition. Figure 21 shows that no single primary factor led to the majority of infrastructure safety reports, but the following three categories made up almost 40 of them: calibration/settings or software controls, environment (weather, power disruption, other), and inadequate or non-working equipment. Figure 22 shows that the number of refuelings normalized by the number of safety reports per quarter has improved by a factor of 10 since the beginning of the project, and Figure 23 shows that no serious (incident or near-miss) reports have occurred in the last three reporting quarters.

- Refueling Events: Hydrogen vehicle refueling needs to be as similar as possible to conventional vehicle refueling to allow an easier commercial market introduction. Over 3,700 refueling events have been analyzed to date, and the amount, time, and rate have been quantified. The average time to refuel was 4.19 minutes with $78 \%$ of the refueling events taking less than 5 minutes (Figure 24). The average amount per fill was $2.15 \mathrm{~kg}$, reflecting both the limited storage capacity of these vehicles ( $4 \mathrm{~kg}$ max $)$ and peoples' comfort level with letting the fuel gauge get close to empty (Figure 25). DOE's target refueling rate is $1 \mathrm{~kg} /$ minute, and these Learning Demo results indicate an average of 
$0.71 \mathrm{~kg} / \mathrm{min}$ and a median of $0.75 \mathrm{~kg} / \mathrm{min}$, with $20 \%$ of the refueling events exceeding 1 $\mathrm{kg} / \mathrm{minute}$ (Figure 26). Therefore, we can conclude that high-pressure gases are approaching adequate refueling times and rates for consumers; however, the challenge is still in packaging enough high-pressure hydrogen onboard to provide adequate range, or finding alternate advanced hydrogen storage materials that can replace the need for highpressure tanks. See Figure 27, Figure 28, and Figure 29 for the status of the firstgeneration storage tanks validated.

- Other Infrastructure Metrics: The amount of hydrogen produced or dispensed has also been tracked by quarter. This result is shown in Figure 30. Note that the amount of hydrogen produced is not the same as the amount dispensed because the project includes a power park at which the unused hydrogen can be converted back into grid electricity during peak utility load periods (due to late afternoon air-conditioning loads) using onsite fuel cells. As discussed earlier, there are four major types of hydrogen refueling stations being demonstrated (shown in Figure 31) and the rate of introduction of these stations is shown in Figure 32.

\subsection{Conclusions and Future Directions}

NREL has now analyzed the first two years of the 5-year project with 77 vehicles now in fleet operation, 12 project refueling stations in use, and no major safety problems encountered. We've analyzed data from 141,000 individual vehicle trips covering 570,000 miles traveled and $20,000 \mathrm{~kg} \mathrm{H}_{2}$ produced or dispensed. Last fall we supported a September 2006 DOE MYPP milestone to evaluate on-road fuel cell durability through voltage degradation and comparison to the 1,000-hour target. The results included an individual team-average high of over 1,250 hours with the 4-team average still over 700 hours. We've analyzed fuel cell system efficiency at 1/4power and compared it to the DOE target of $60 \%$; system efficiency results from the four teams ranged between $52.5 \%$ and $58.1 \%$. We've published 30 composite data products to date and made them directly accessible to the public from a new Web site.

As we move forward in the future, we will identify any correlations of real-world factors influencing fuel cell degradation and strive to separate their interwoven dependencies. We will create new and updated composite data products based on data through June 2007, and prepare results for publication at EVS-23 and 2007 Fuel Cell Seminar as the "Fall 2007" results. We will also support the September 2007 DOE MYPP and Joule milestone on refueling times and rates. For the $2^{\text {nd }}$ generation vehicles initially introduced this fall, we will evaluate improvements in fuel cell durability, range, fuel economy, and safety. We will semi-annually (spring/fall) compare technical progress to program objectives and targets, providing public outputs through publication at conferences. As an important part of the project, we will identify opportunities to feed project findings back into HFCIT Program R\&D activities to maintain the project as a "learning demonstration." 


\subsection{Related Publications/Presentations from FY07}

1. Wipke, K., "Hydrogen Secure Data Center: Procedures to Protect Technical Data Submitted under the Controlled Hydrogen Fleet and Infrastructure Demonstration and Validation Project," Golden, CO: National Renewable Energy Laboratory, updated June 2007.

2. Wipke, K., Welch, C., Thomas, H., Sprik, S., "Controlled Hydrogen Fleet and Infrastructure Analysis," DOE Annual Merit Review Meeting, Washington, DC, May 2007. (presentation)

3. Wipke, K., "Composite Data Products for the Controlled Hydrogen Fleet and Infrastructure Demonstration and Validation Project," Golden, CO: National Renewable Energy Laboratory, updated March 2007. (online at http://www.nrel.gov/hydrogen/cdp topic.html).

4. Wipke, K., Welch, C., Thomas, H., Sprik, S., Gronich, S., Garbak, J., Hooker, D., "Fuel Cell Vehicle Learning Demonstration: Spring 2007 Results," NHA Annual Hydrogen Meeting and Exposition, San Antonio, TX, March 2007. (presentation)

5. Wipke, K., Welch, C., Thomas, H., Sprik, S., Gronich, S., Garbak, J., “Controlled Hydrogen Fleet and Infrastructure Demonstration and Validation Project: Initial Fuel Cell Efficiency and Durability Results," World Electric Vehicle Association Journal, December 2006. (paper)

6. Wipke, K., Welch, C., Thomas, H., Sprik, S., "Controlled Hydrogen Fleet and Infrastructure Analysis Project," 2006 DOE HFCIT Program Annual Progress Report, November 2006. (paper)

7. Wipke, K., Welch, C., Thomas, H., Sprik, S., Gronich, S., Garbak, J., "Hydrogen Leaning Demonstration Project: Fuel Cell Efficiency and Initial Durability," Fuel Cell Seminar, November 2006. (extended abstract and presentation)

8. Wipke, K., presentation of Learning Demonstration results to FreedomCAR Vehicle Systems Analysis Tech Team, July 12, 2006 and Nov. 8, 2006.

9. Wipke, K., presentation of Learning Demonstration results to FreedomCAR Fuel Cell Tech Team, October 18, 2006.

10. Wipke, K., Welch, C., Thomas, H., Sprik, S., Gronich, S., Garbak, J., "Hydrogen Fleet \& Infrastructure Demonstration and Validation Project: Fall 2006 Progress Update," EVS22, Yokohama, Japan, October 2006. (paper and presentation)

11. Wipke, K., Welch, C., Thomas, H., Sprik, S., Gronich, S., Garbak, J., "Hydrogen Fleet \& Infrastructure Demonstration and Validation Project: Fall 2006 Progress Update," CARB ZEV Technology Symposium, September 25, 2006. (presentation)

12. Wipke, K., presentation of Learning Demonstration results to FreedomCAR Hydrogen Storage Tech Team, September 21, 2006. 
13. Wipke, K., presentation of Learning Demonstration results to FreedomCAR Codes and Standards Tech Team, June 5, 2006.

14. Welch, C., Wipke, K., Thomas, H., Sprik, S., “DOE's Controlled Hydrogen Fleet and Infrastructure Demonstration and Validation Project: Quarterly Validation Assessment Reports," (HSDC papers only)

- 1Q 2006, May 2006.

- 2Q 2006, August 2006.

- 3Q 2006, December 2006.

- 4Q 2006, March 2007.

\subsection{Acronyms}

CDP

FAT

FCV

FY

gge

$\mathrm{H}_{2}$

HFCIT

HSDC

MYPP

NHA

NREL

$R \& D$ composite data product

Fleet Analysis Toolkit (software tool developed at NREL) fuel cell vehicle

fiscal year

gallon of gasoline equivalent

hydrogen

Hydrogen, Fuel Cells \& Infrastructure Technologies (DOE program)

Hydrogen Secure Data Center (at NREL)

Multi-Year Program Plan (DOE document)

National Hydrogen Association

National Renewable Energy Laboratory

research and development 


\subsection{Composite Data Products Referenced in Previous Discussion}

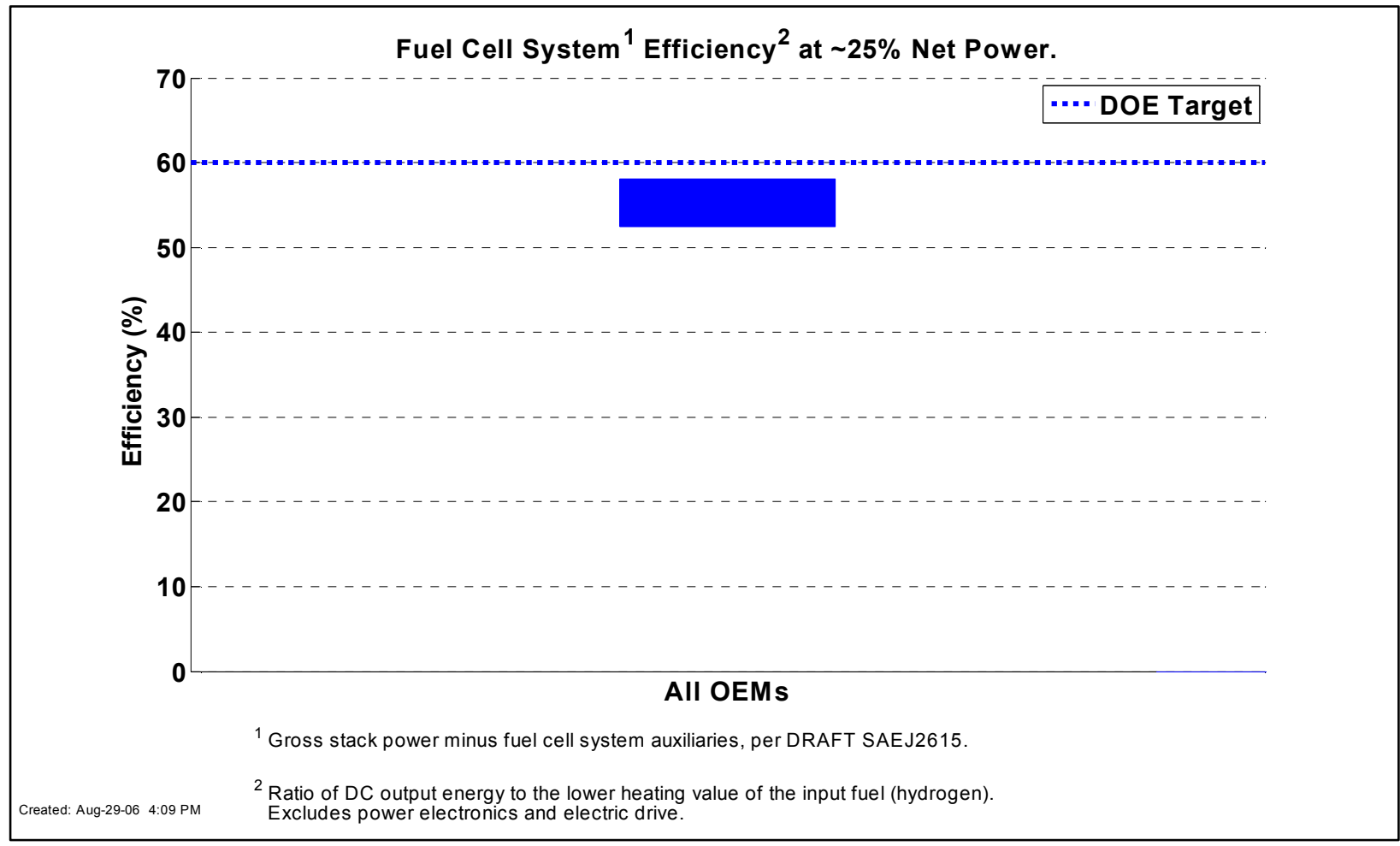

Figure 4: Fuel Cell System Efficiency at $\sim 25 \%$ Net Power

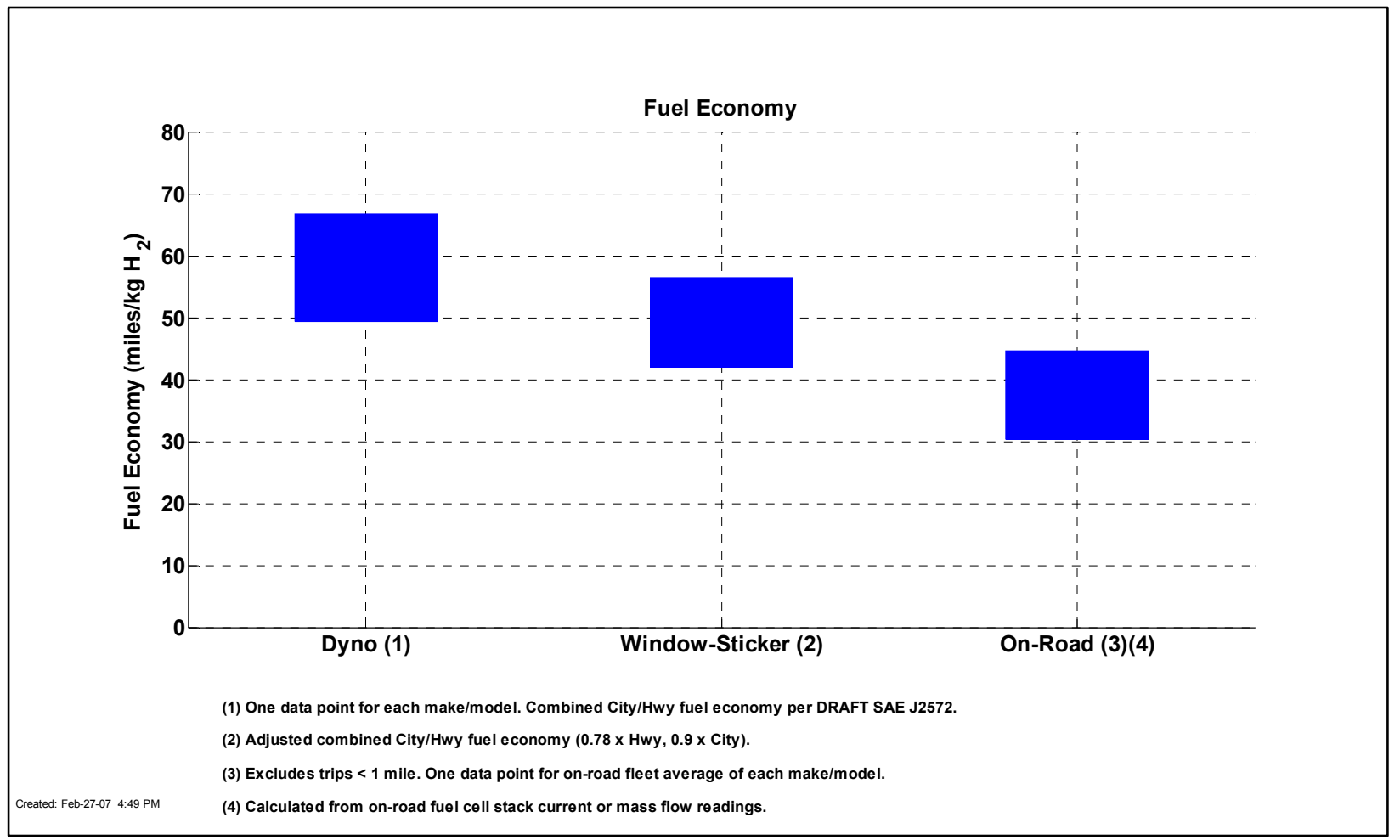

Figure 5: Learning Demonstration Fuel Cell Vehicle Fuel Economy 


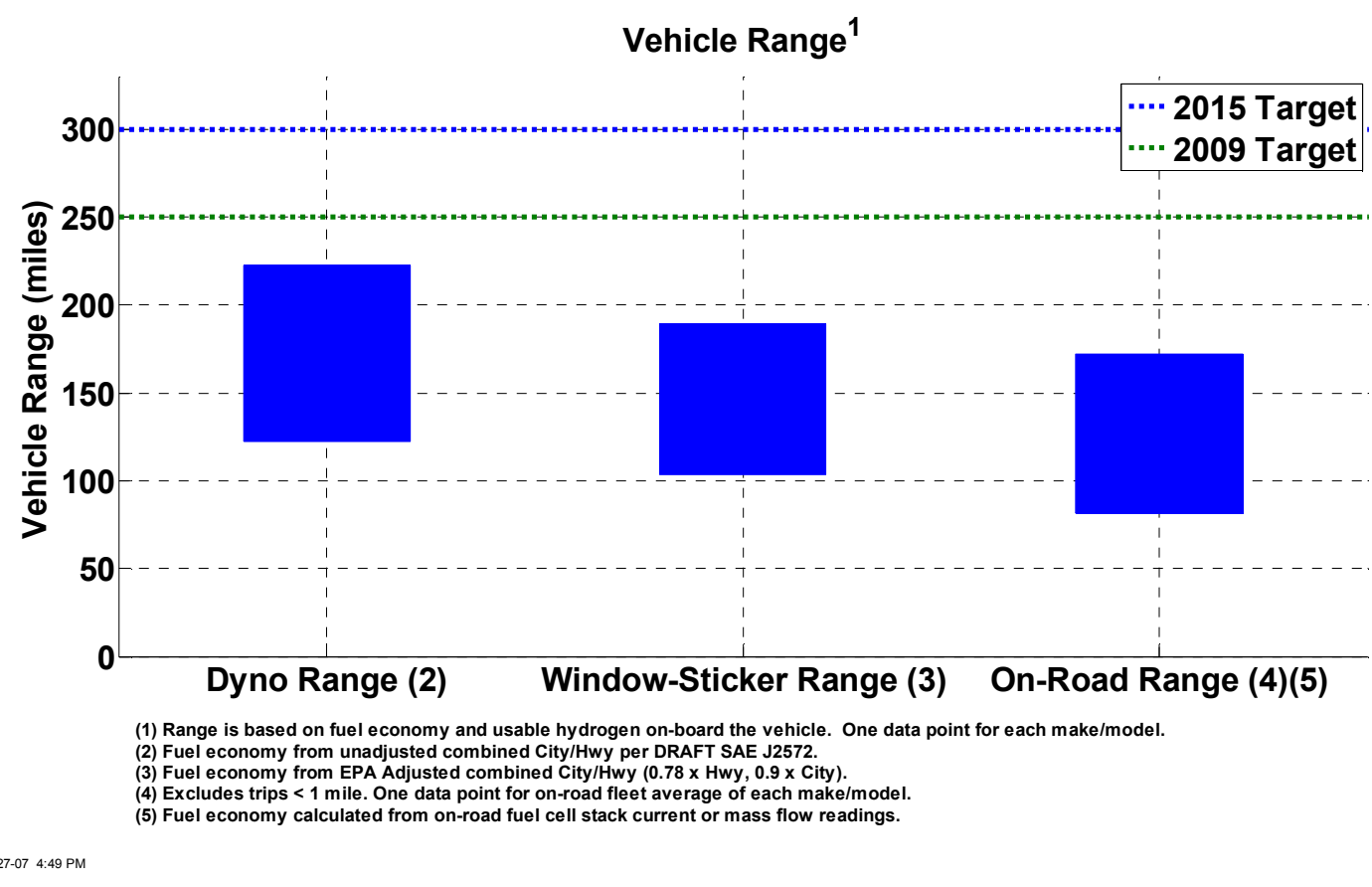

Figure 6: Learning Demonstration Fuel Cell Vehicle Driving Range

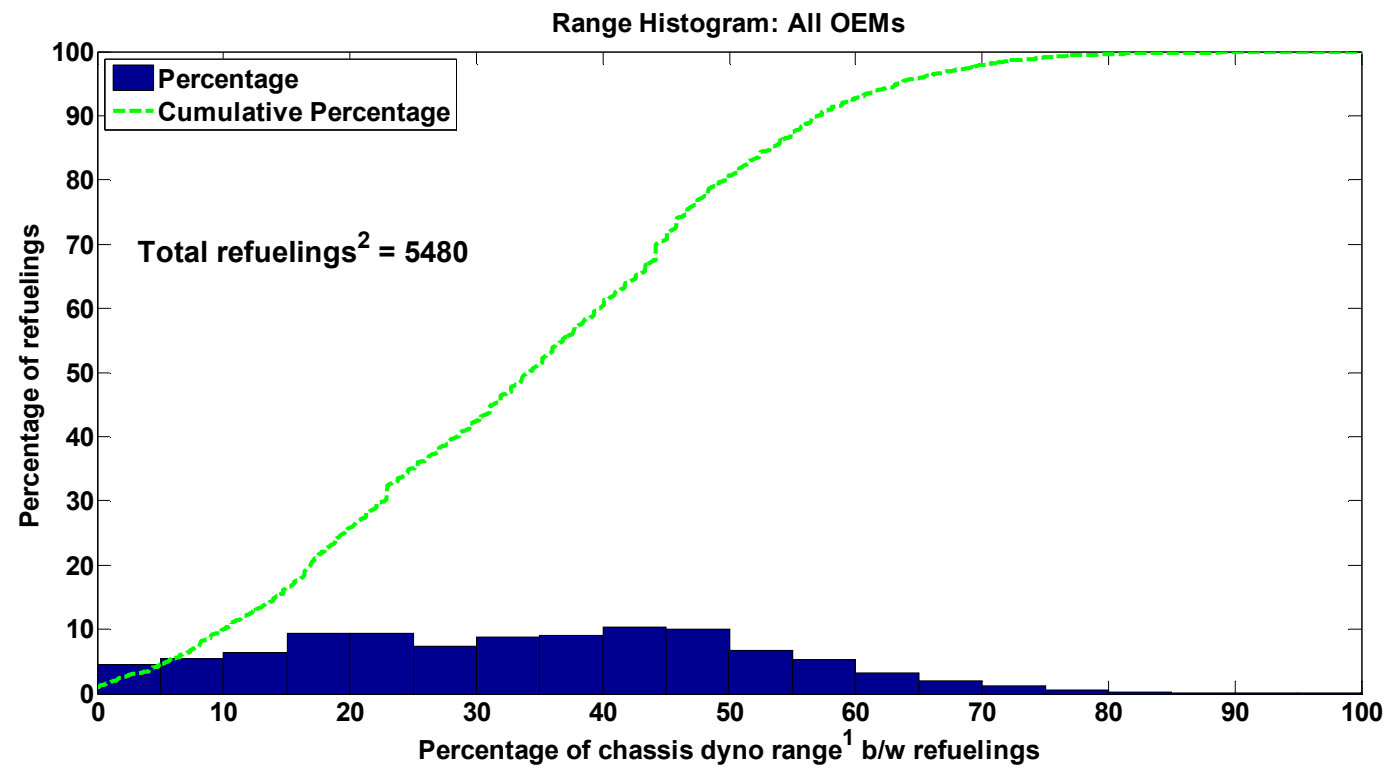

1. Range calculated using the combined City/Hwy fuel economy from dyno testing (not EPA adjusted) and usable fuel on board.

Created: Feb-26-07 12:53 PM $\quad$ 2. Some refueling events are not detected/reported due to data noise or incompleteness

Figure 7: Actual Driving Distances Between Refuelings as a Percentage of Dynamometer Range 


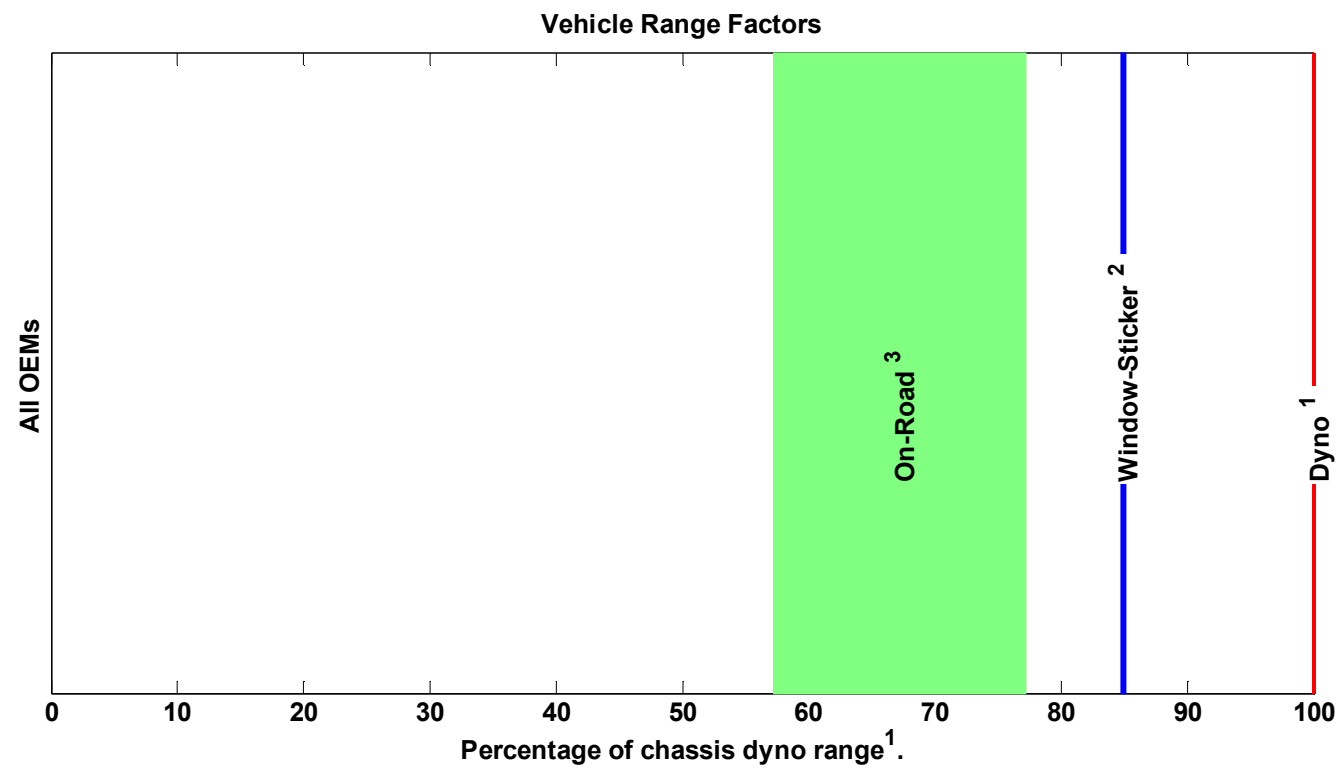

1. Calculated using the combined City/Hwy fuel economy from dyno testing (non-adjusted) and usable fuel on board.

2. Applying window-sticker correction factors for fuel economy: $0.78 \times$ Hwy and $0.9 \times$ City

3. Using fuel economy from on-road data (excluding trips $>1$ mile, consistent with other data products).

Figure 8: On-Road Range Normalized by Dynamometer Range

DOE Learning Demonstration:

Fuel Cell Stack Hours Accumulated Through 2006 Q4

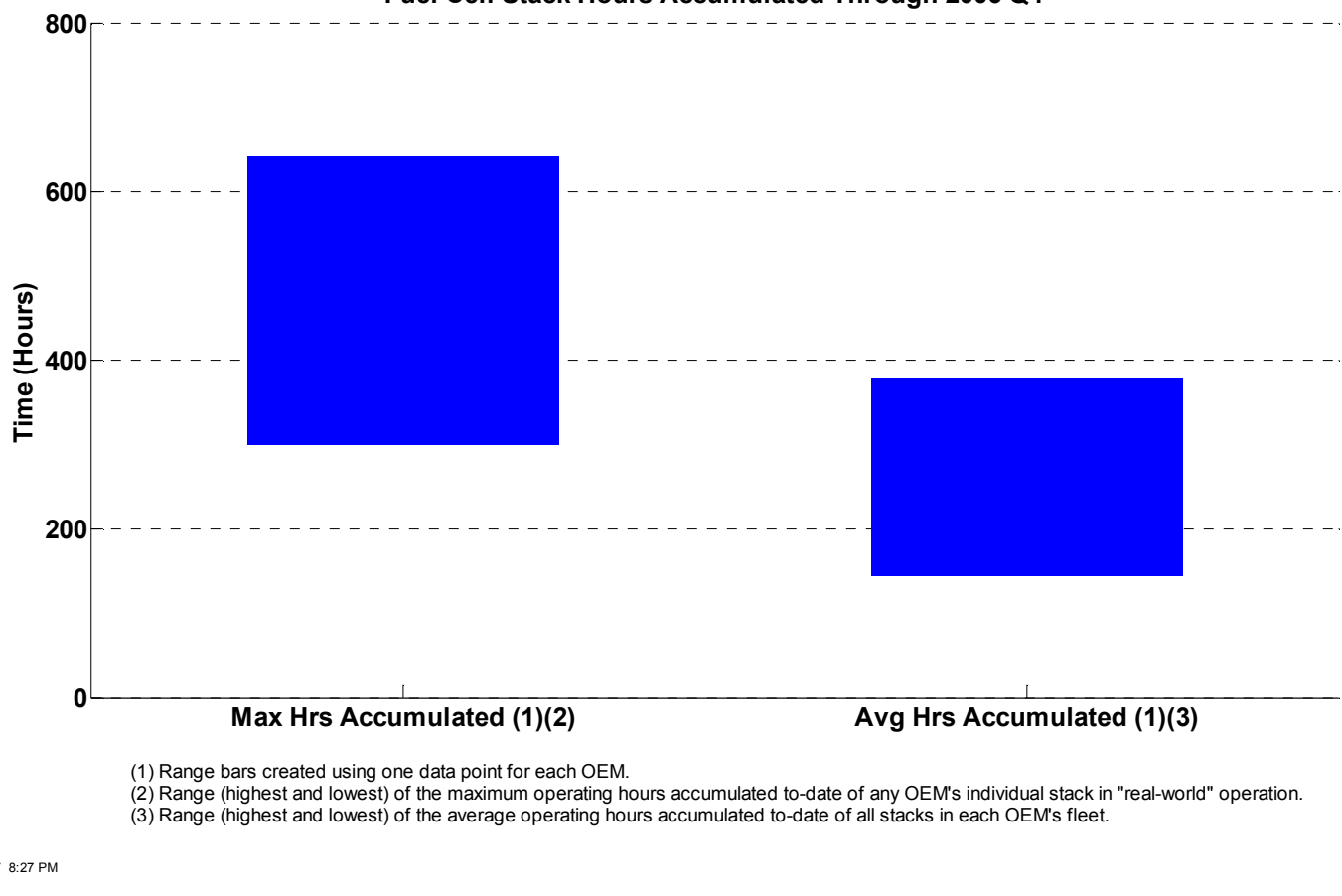

Figure 9: Learning Demonstration Fuel Cell Stack Hours Accumulated through December 2006 


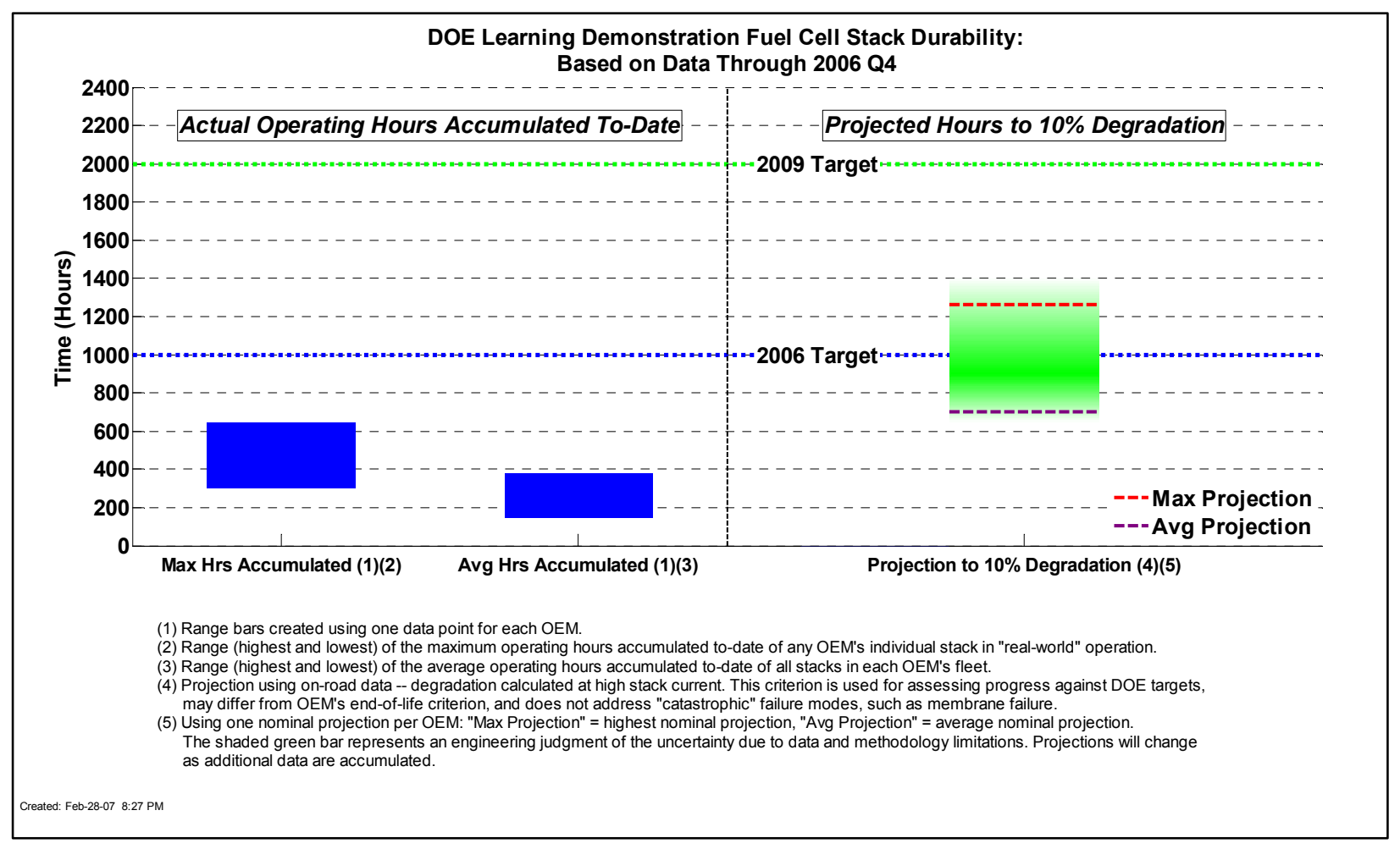

Figure 10: Projected Hours to 10\% Fuel Cell Stack Voltage Degradation

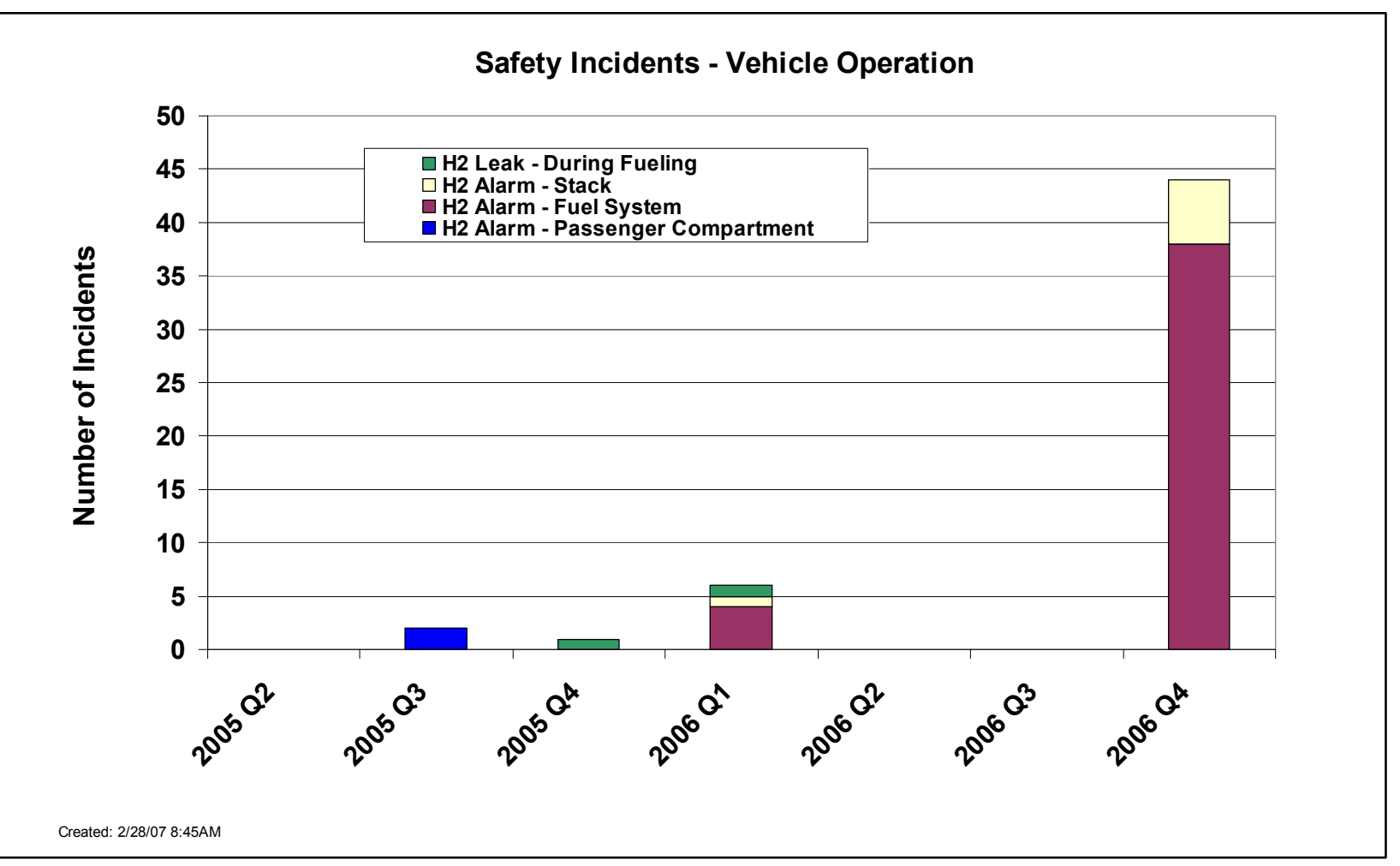

Figure 11: Vehicle Safety Reports by Quarter 


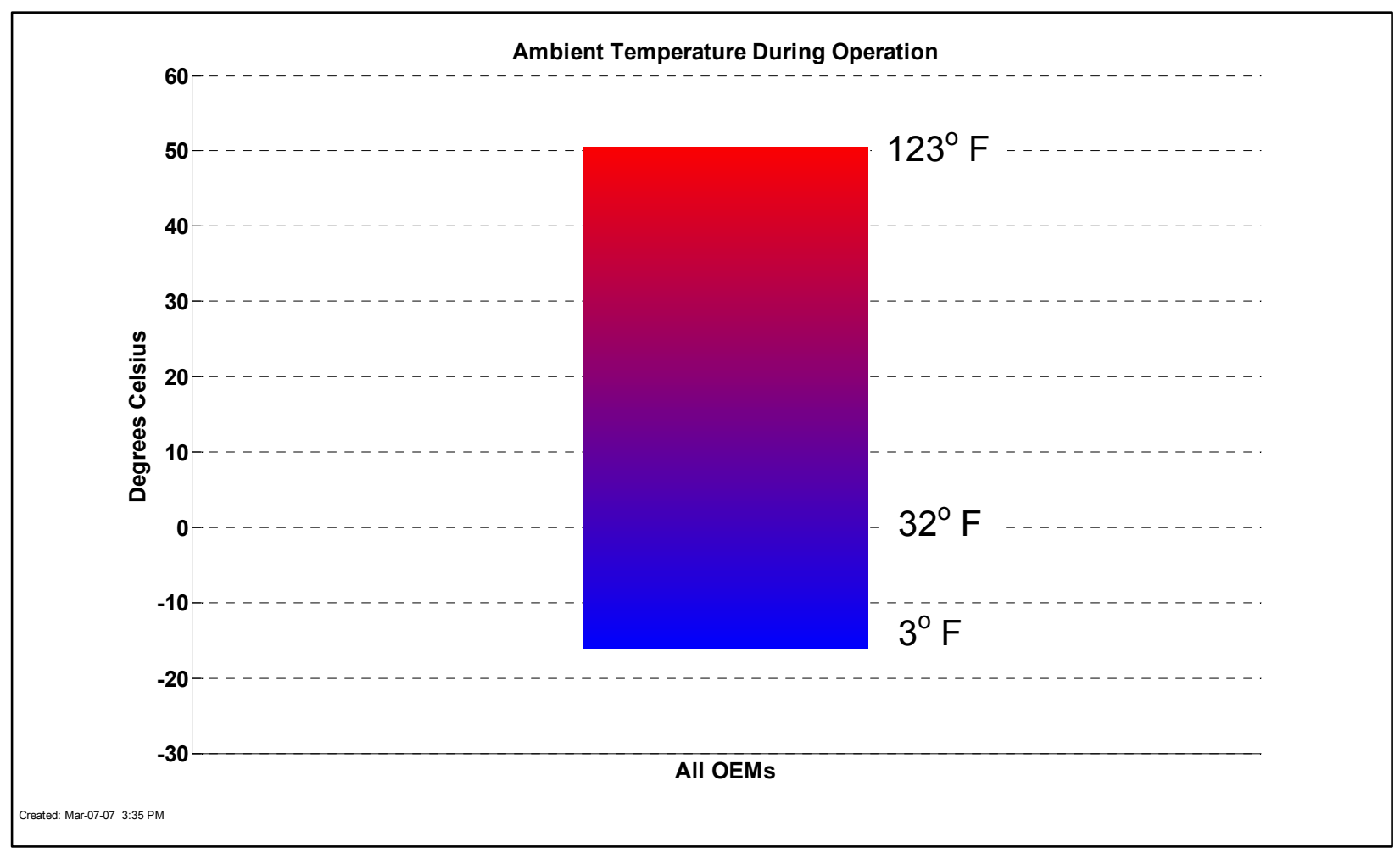

Figure 12: Range of Ambient Temperature during Vehicle Operation

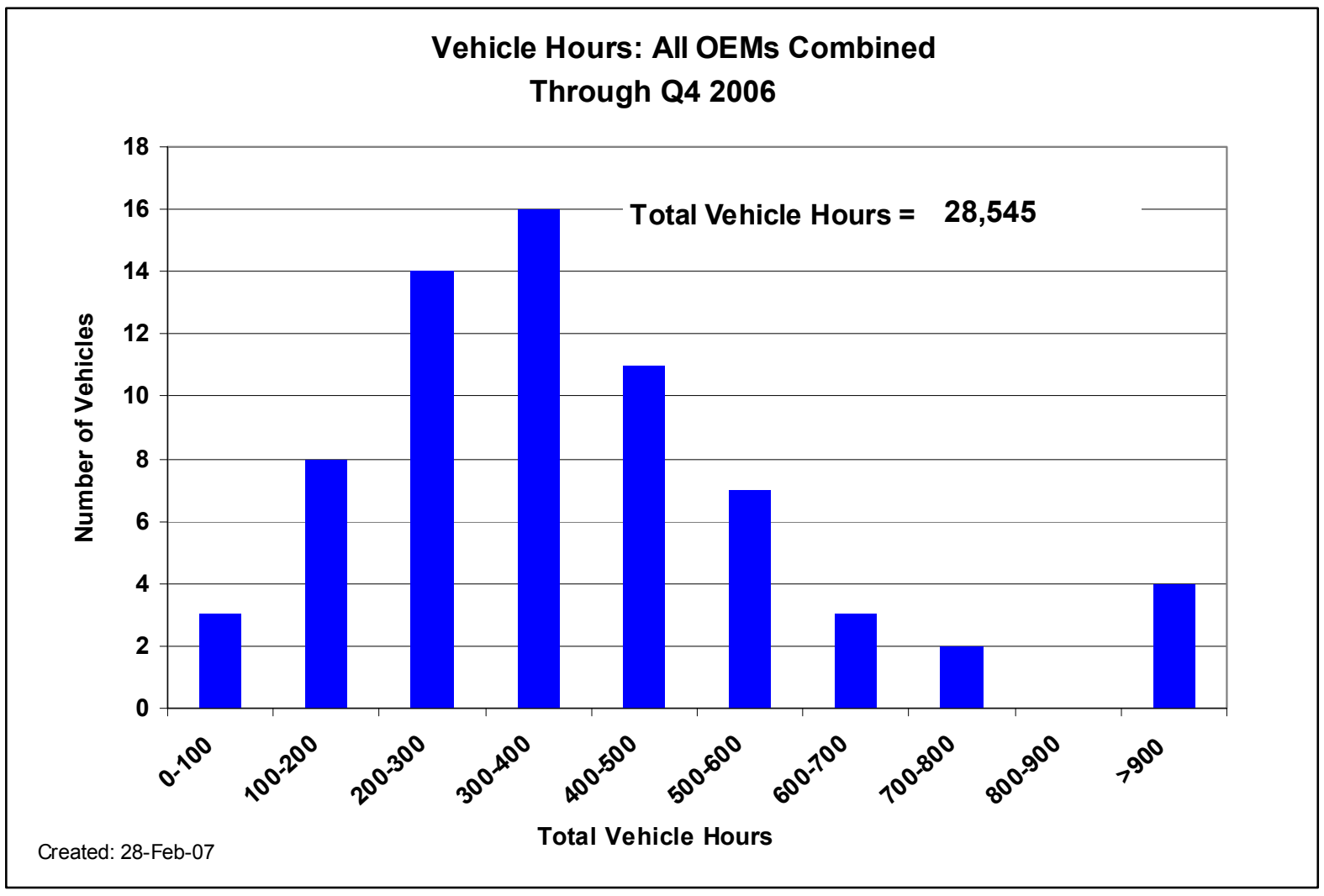

Figure 13: Distribution of Vehicle Operating Hours 


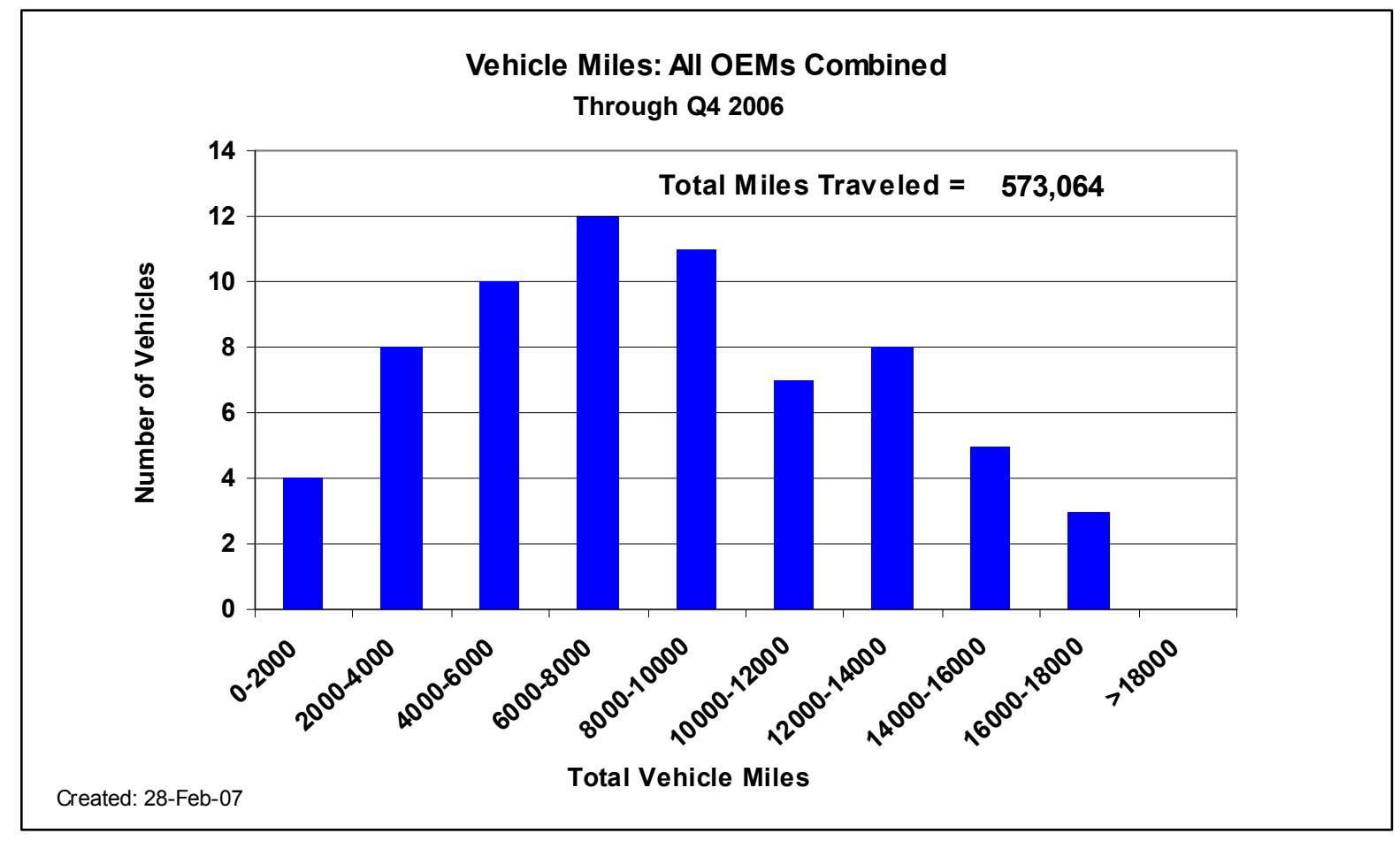

Figure 14: Distribution of Vehicle Miles Traveled

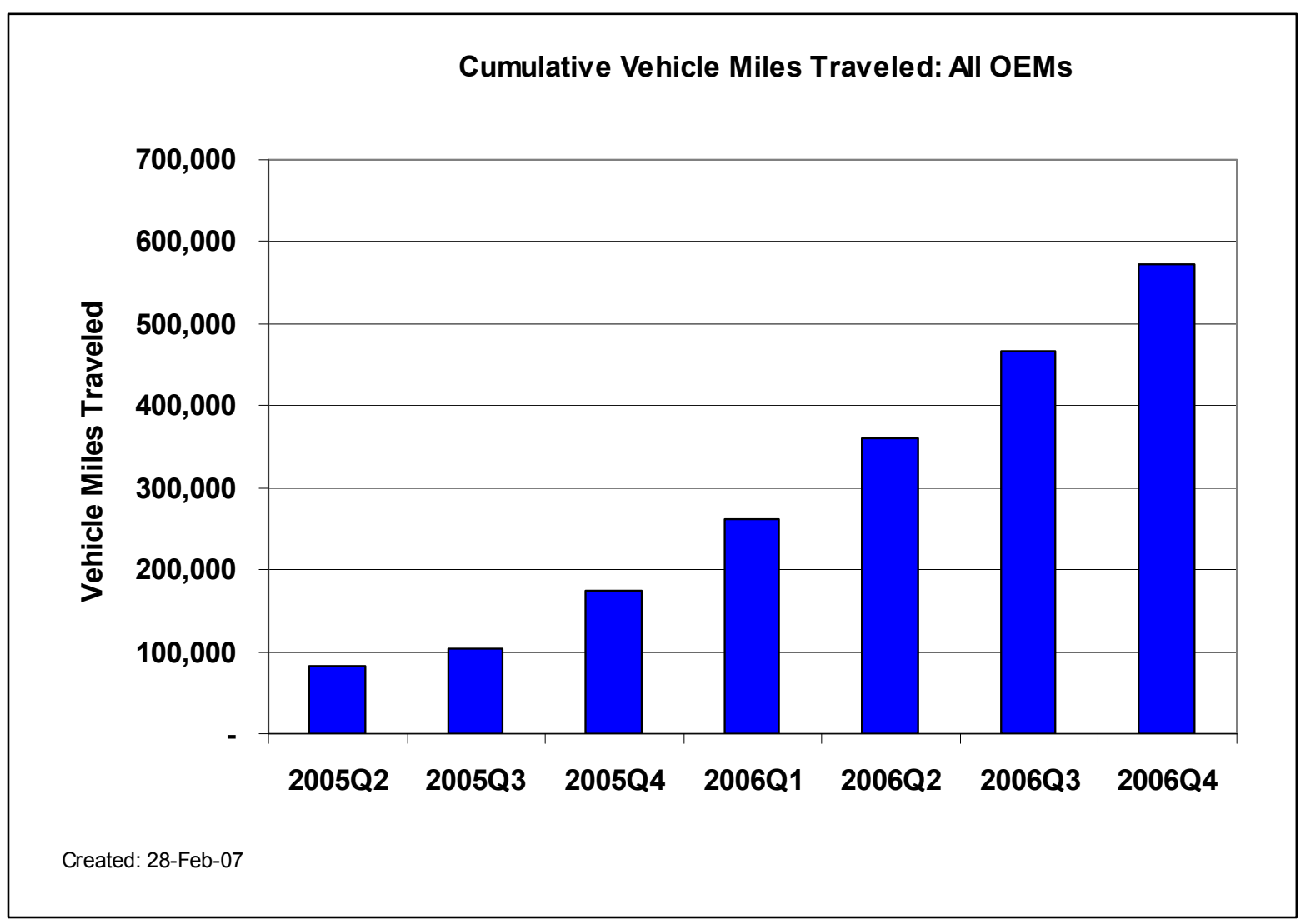

Figure 15: Cumulative Vehicle Miles Traveled by Quarter 


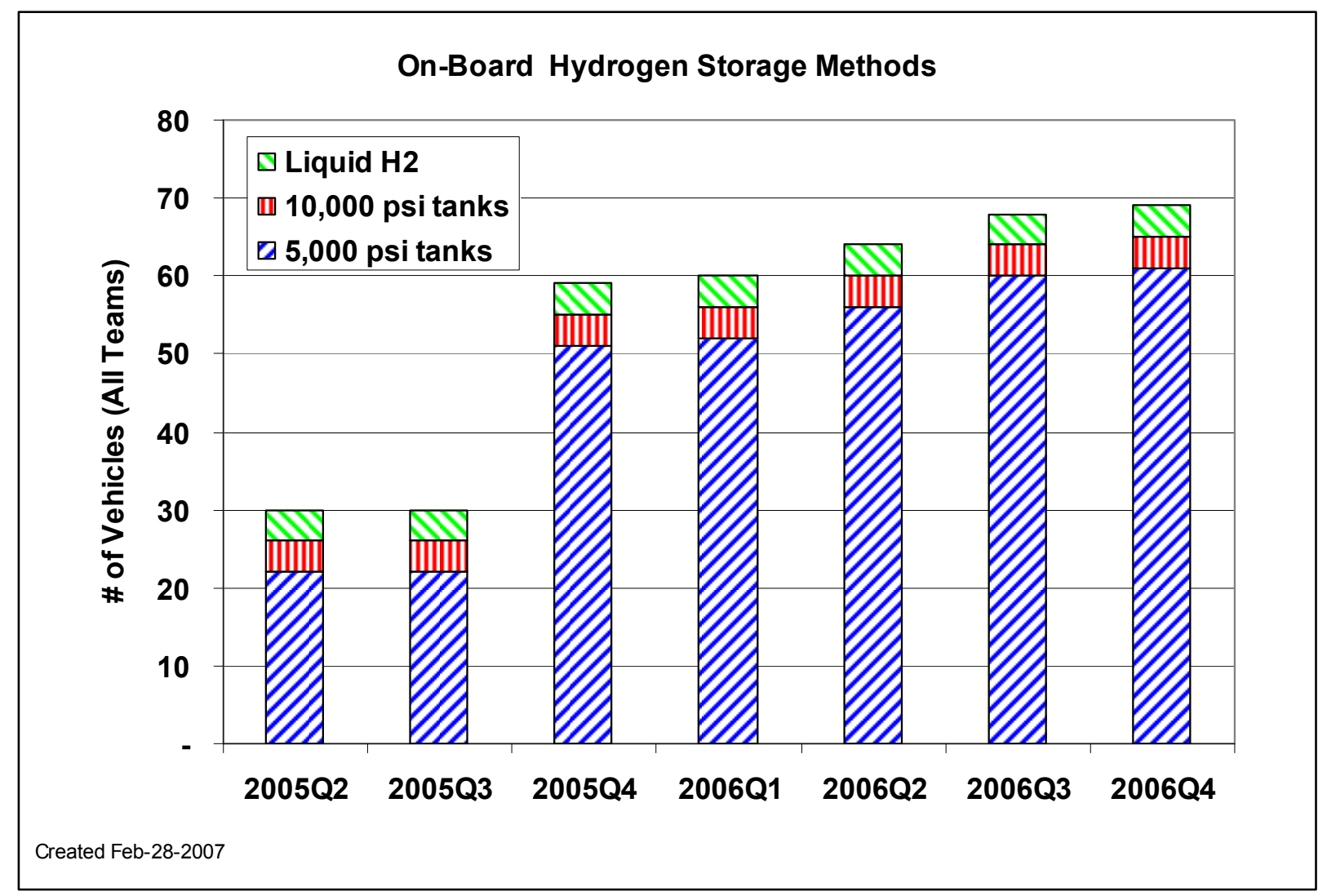

Figure 16: Hydrogen FCVs (and Storage Type) Deployed by Quarter

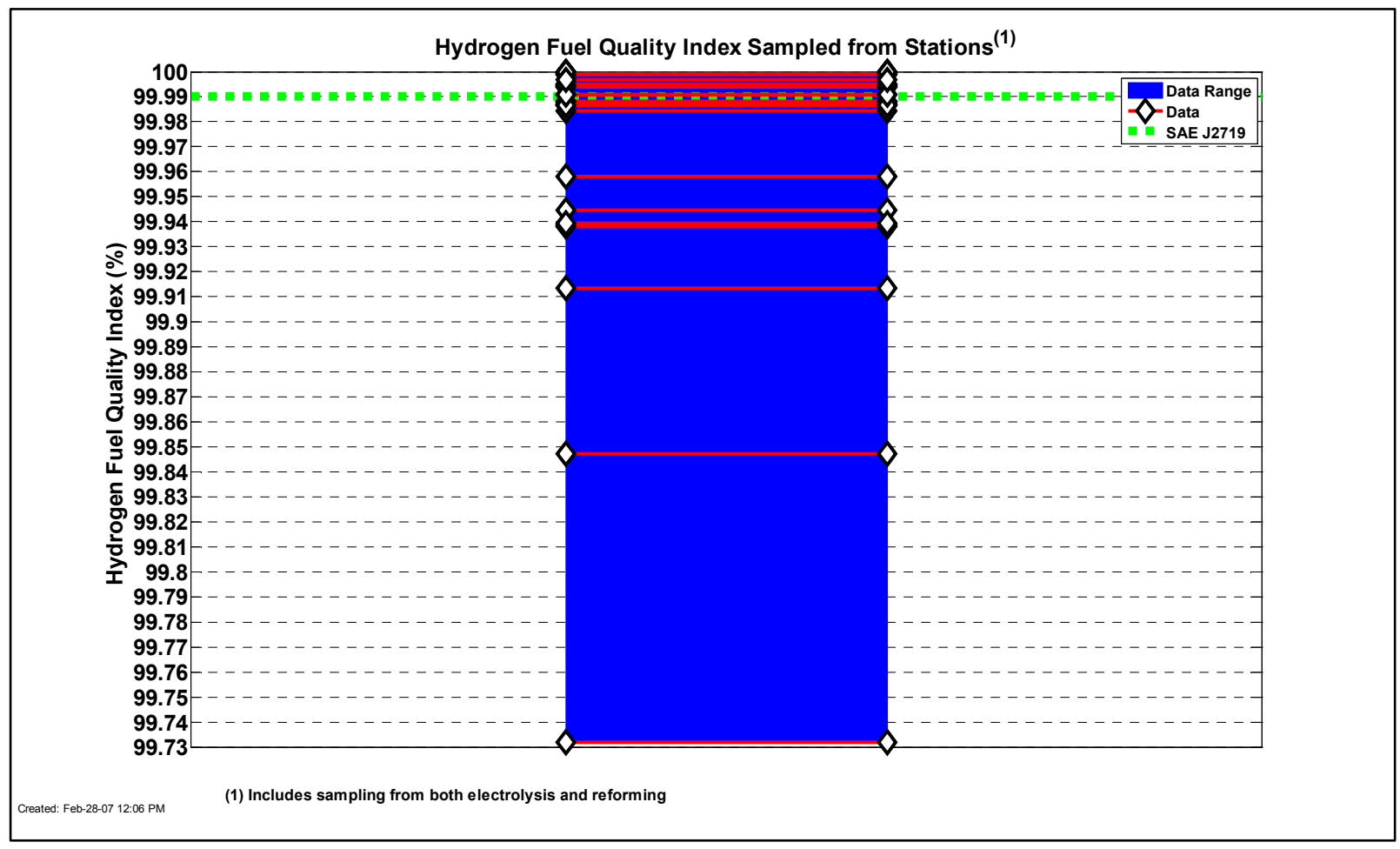

Figure 17: Refueling Infrastructure Hydrogen Quality Index 


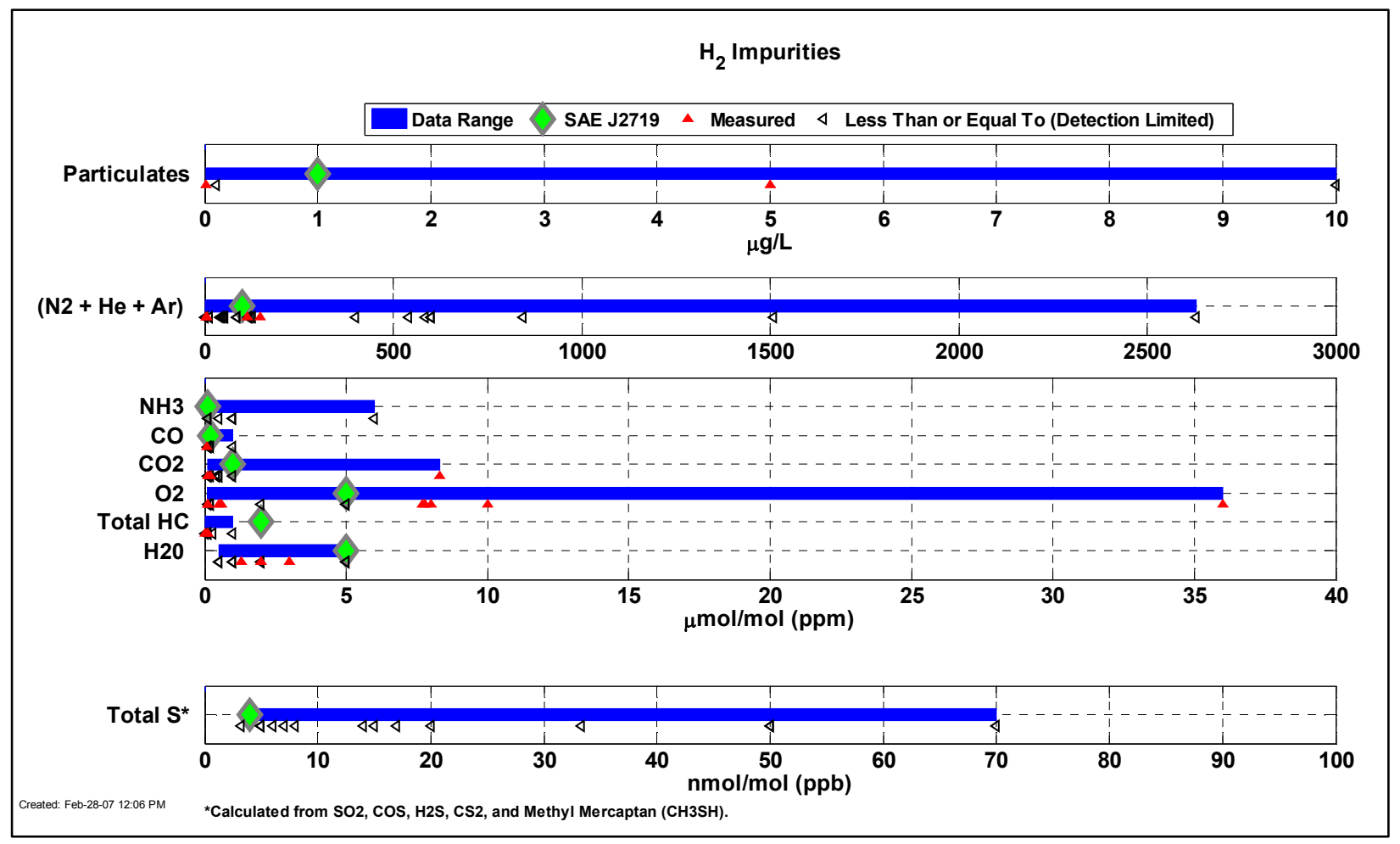

Figure 18: Hydrogen Impurities Sampled from All Stations to Date

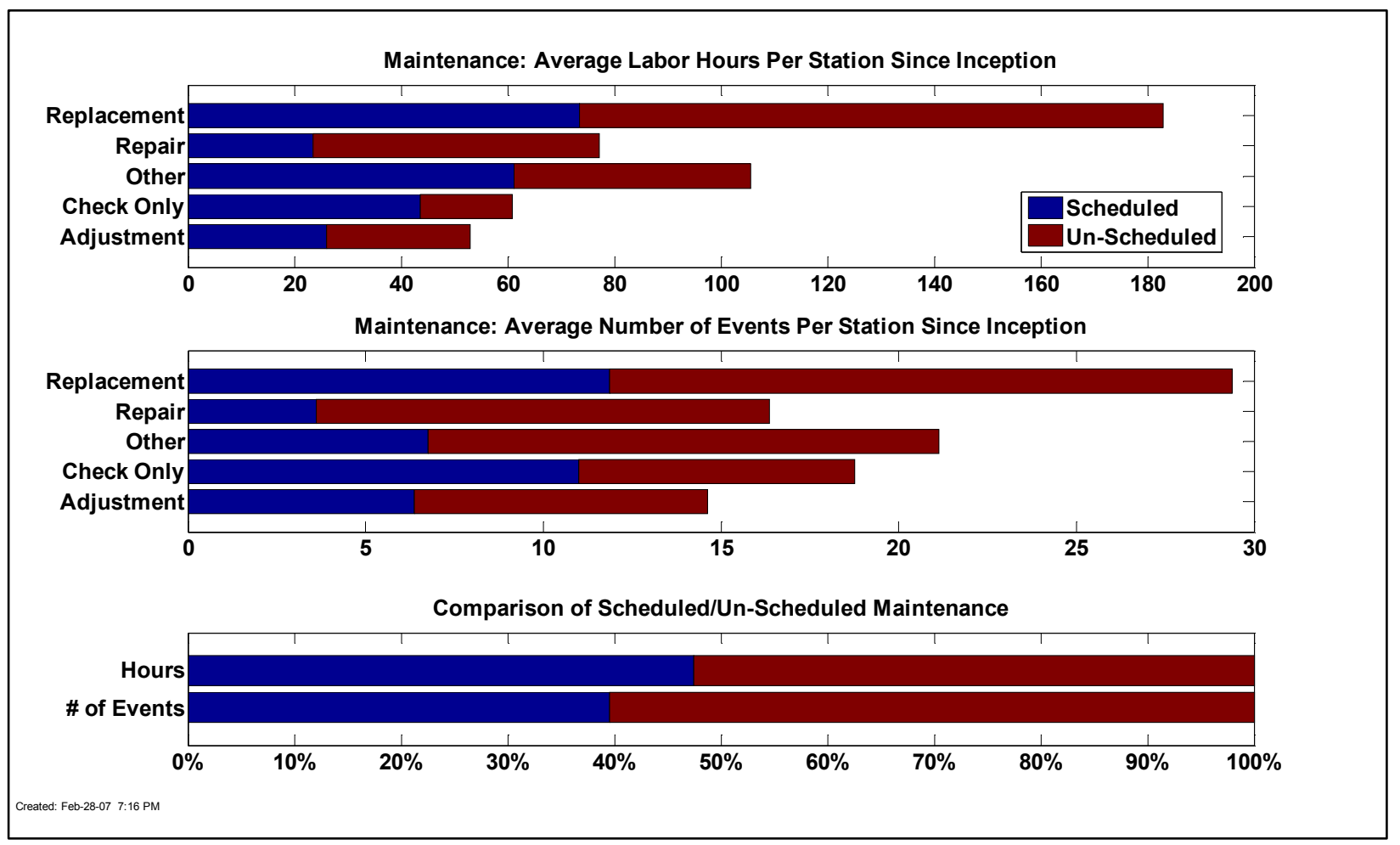

Figure 19: Refueling Infrastructure Maintenance by Hours and Events 


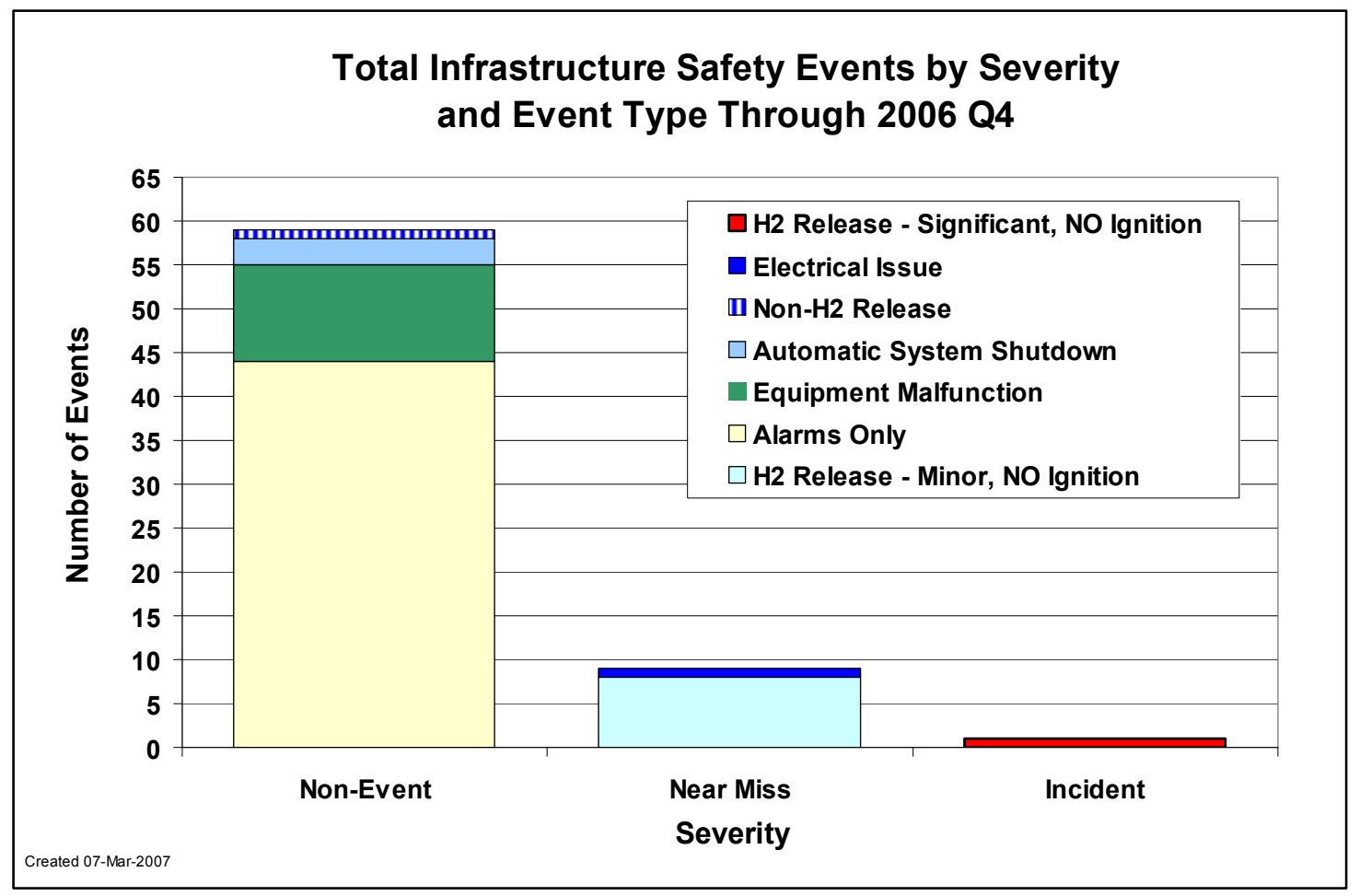

Figure 20: Infrastructure Safety Reports by Severity

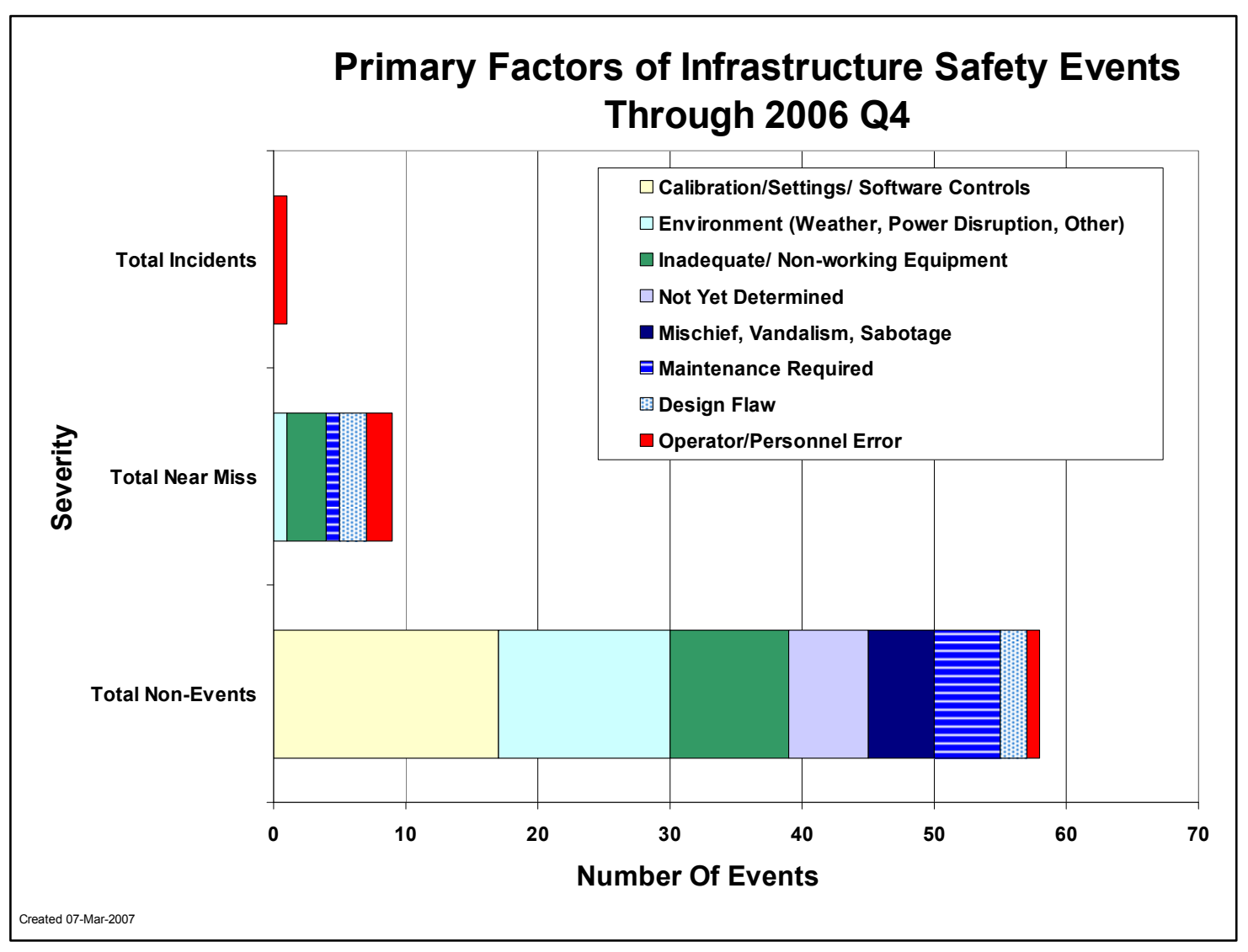

Figure 21: Primary Factors Leading to Infrastructure Safety Reports 


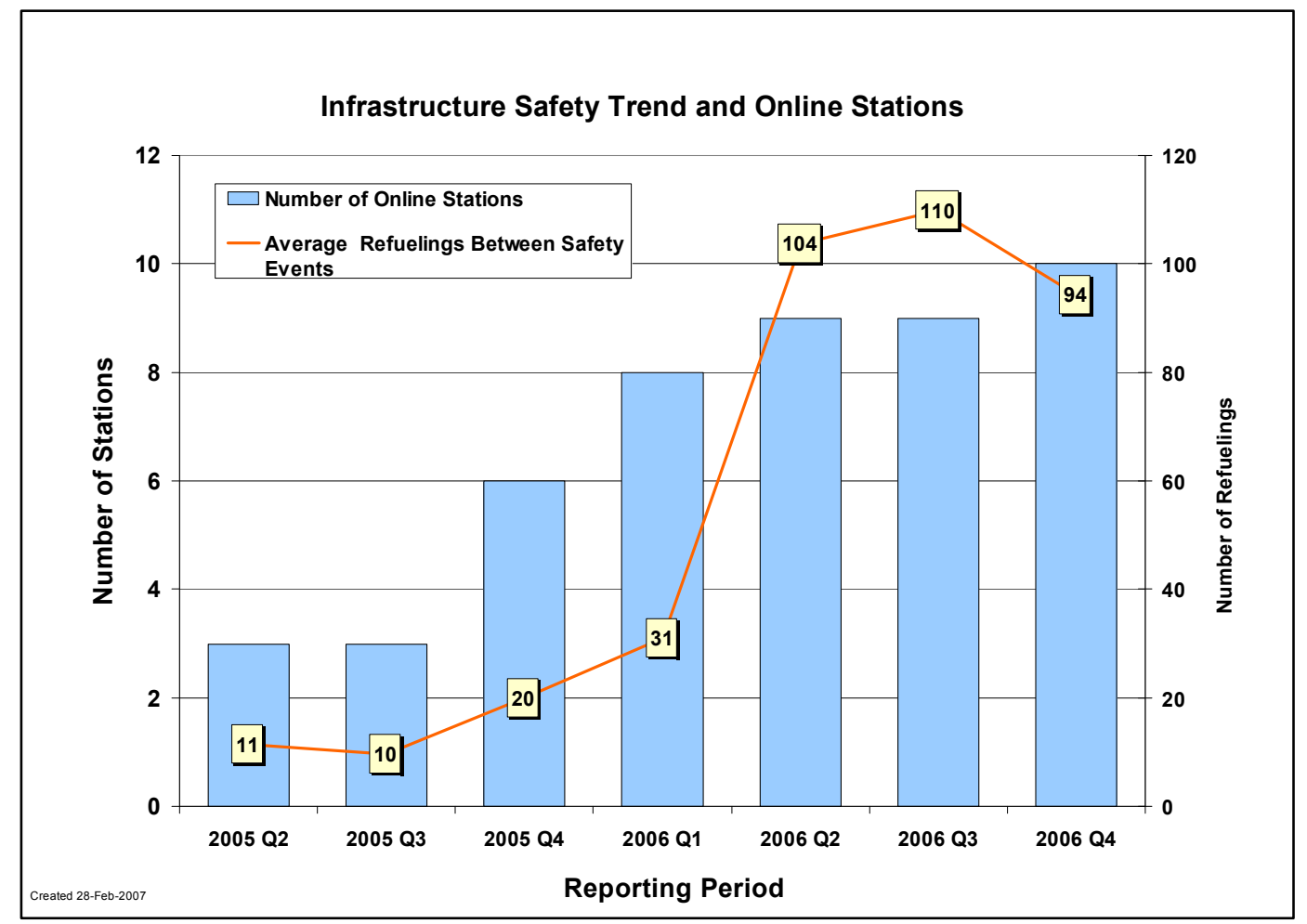

Figure 22: Average Refuelings Between Infrastructure Safety Reports

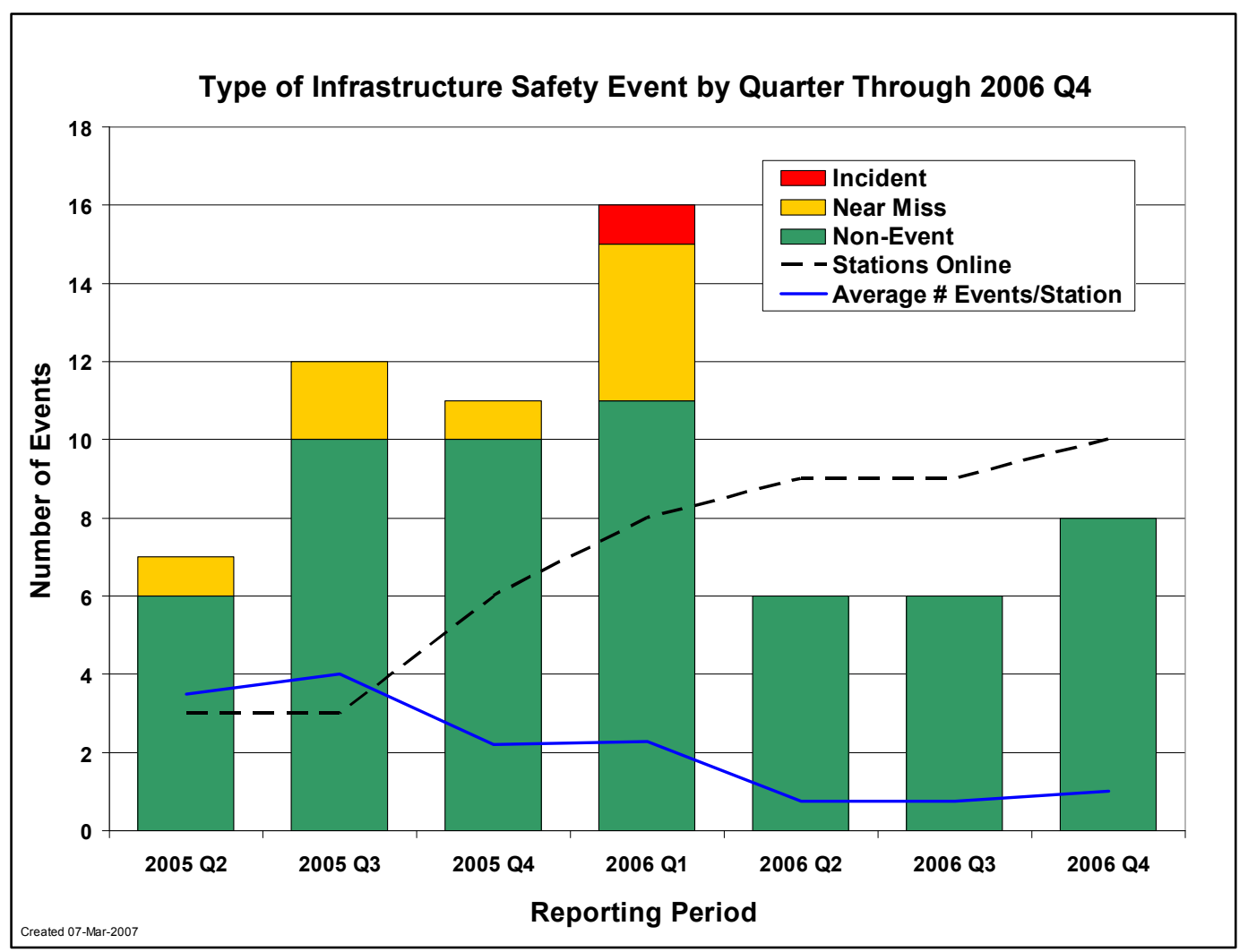

Figure 23: Type of Infrastructure Safety Event by Quarter 


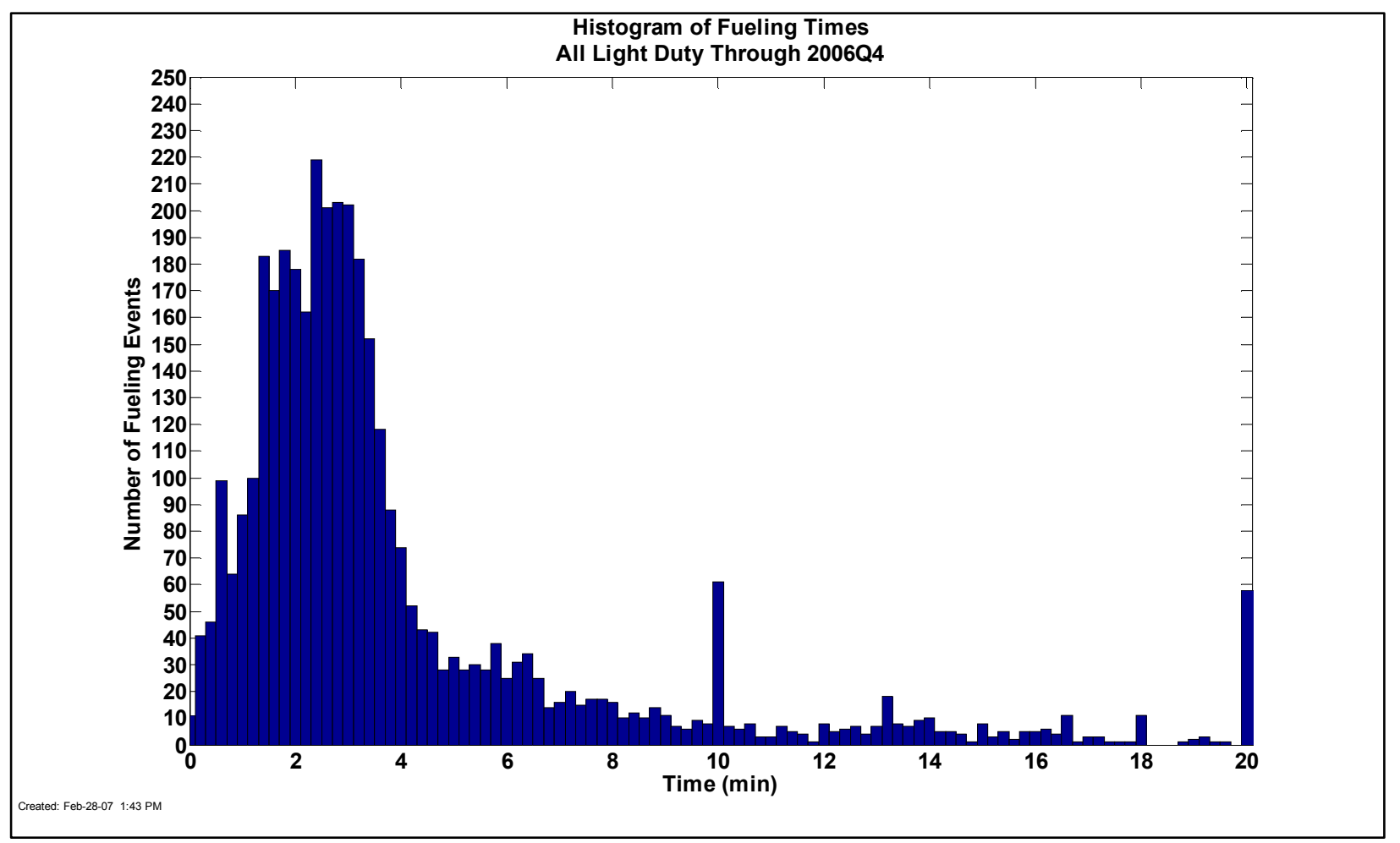

Figure 24: Distribution of Refueling Times

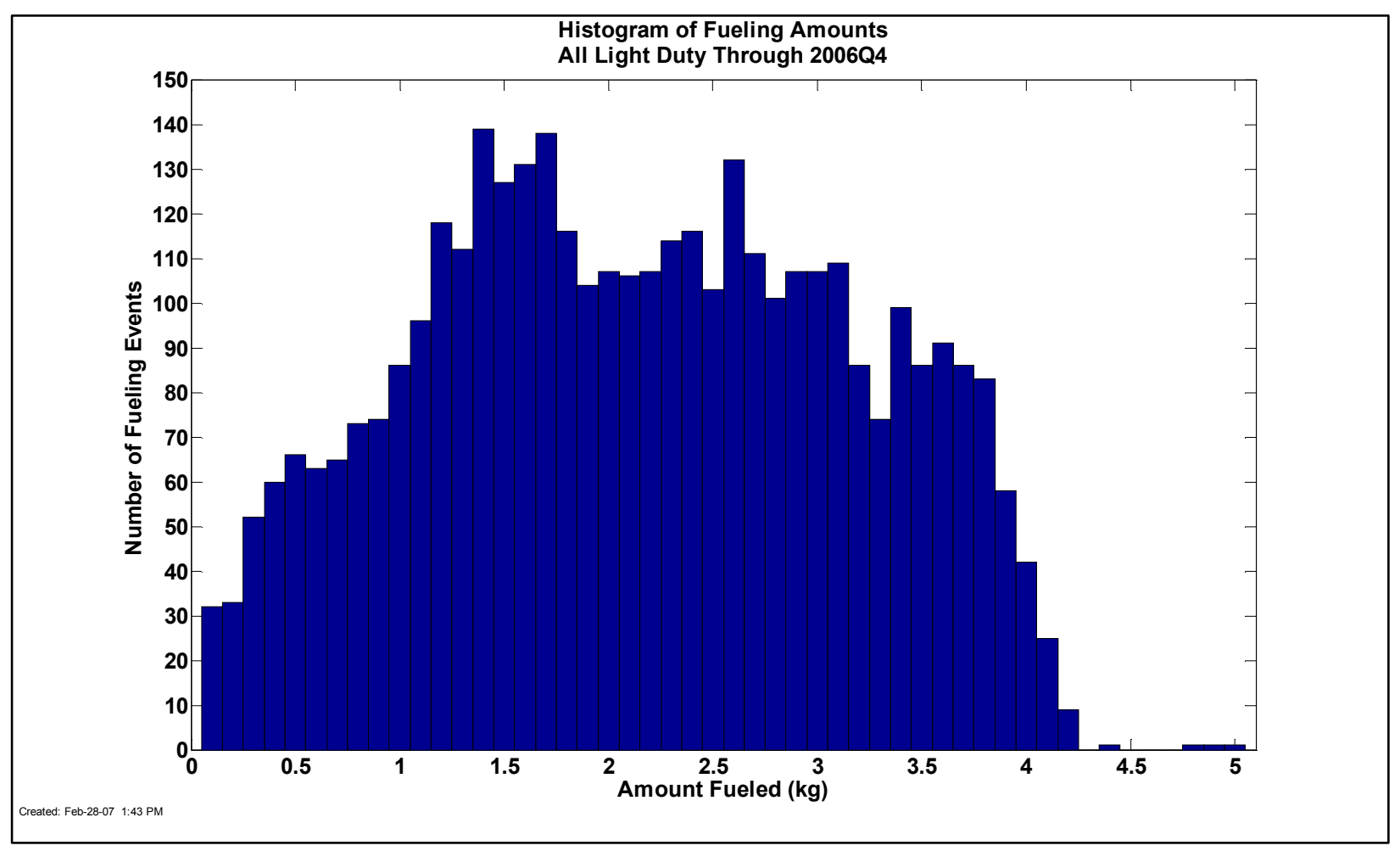

Figure 25: Distribution of Refueling Amounts 


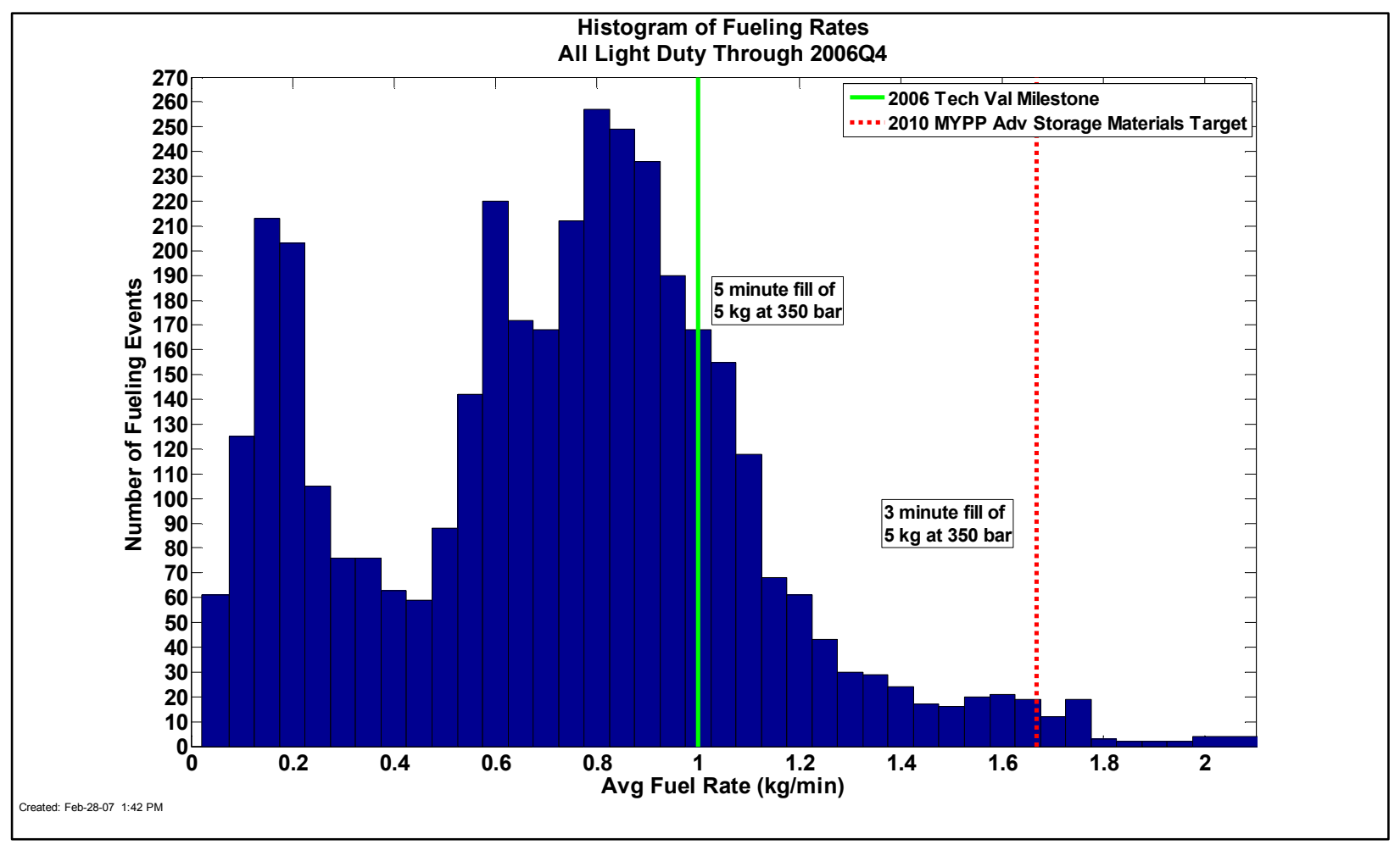

Figure 26: Distribution of Refueling Rates Compared to Targets

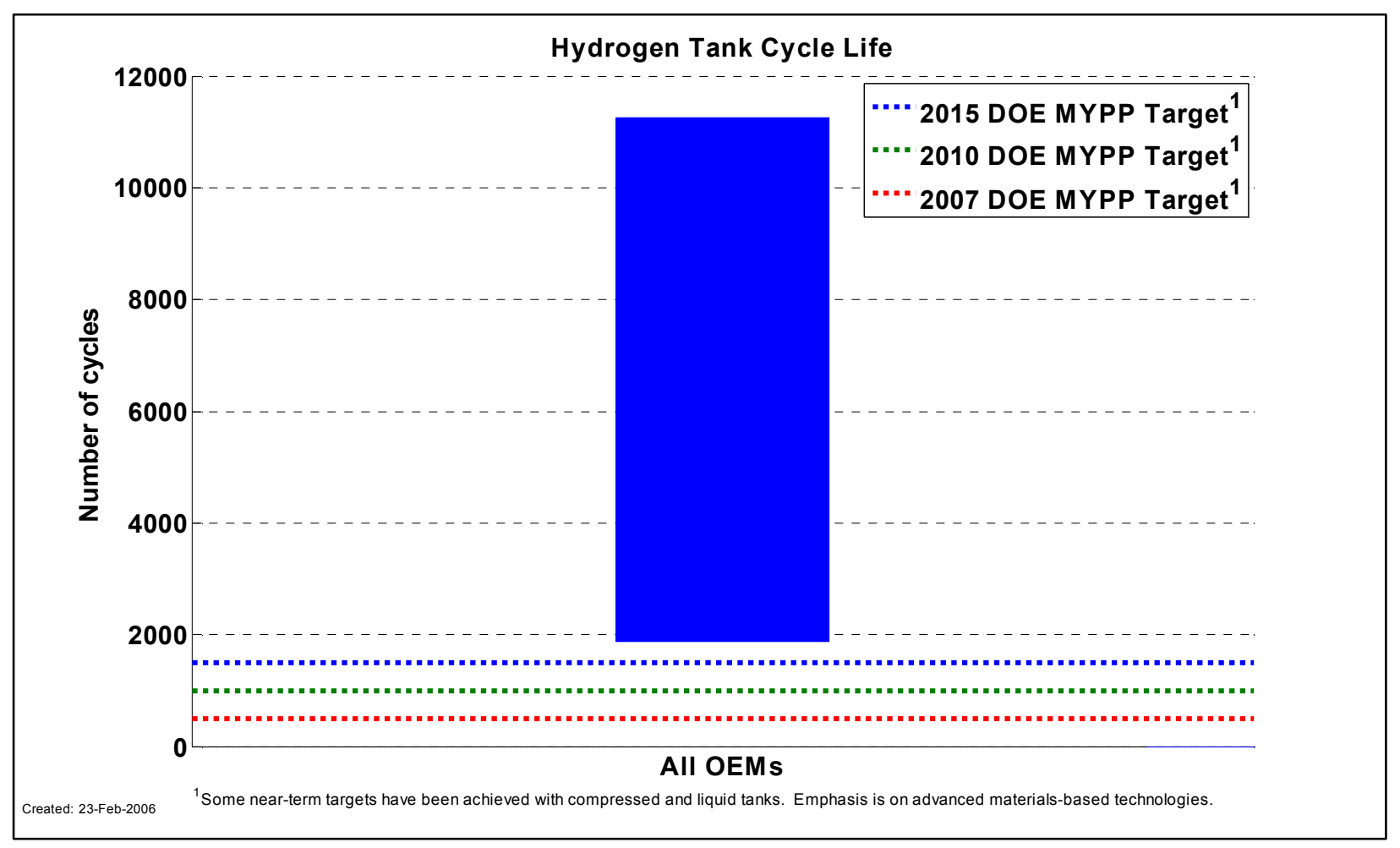

Figure 27: Compressed and Liquid Hydrogen Tank Cycle Life 


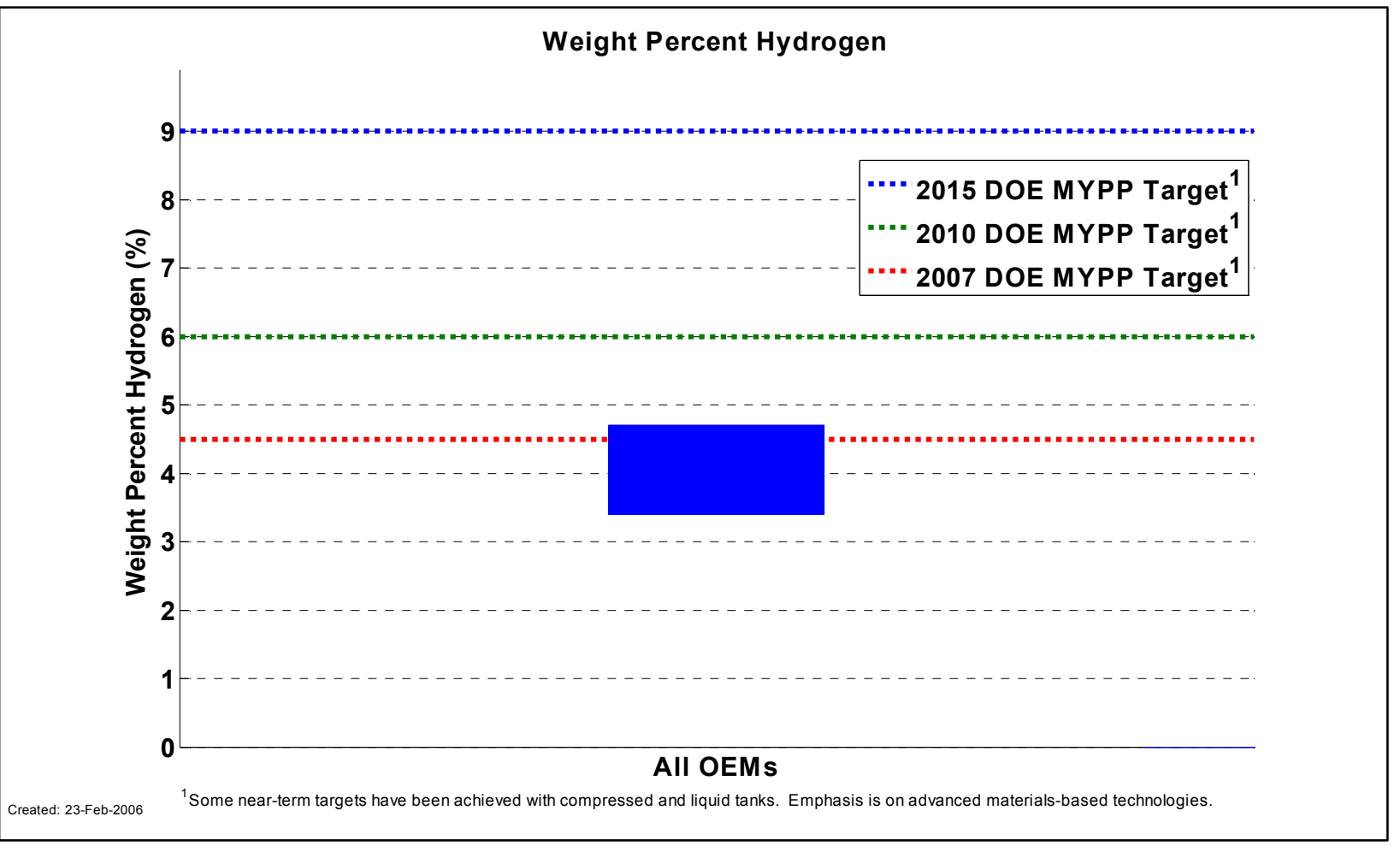

Figure 28: Compressed and Liquid Hydrogen Tank Weight-Percent

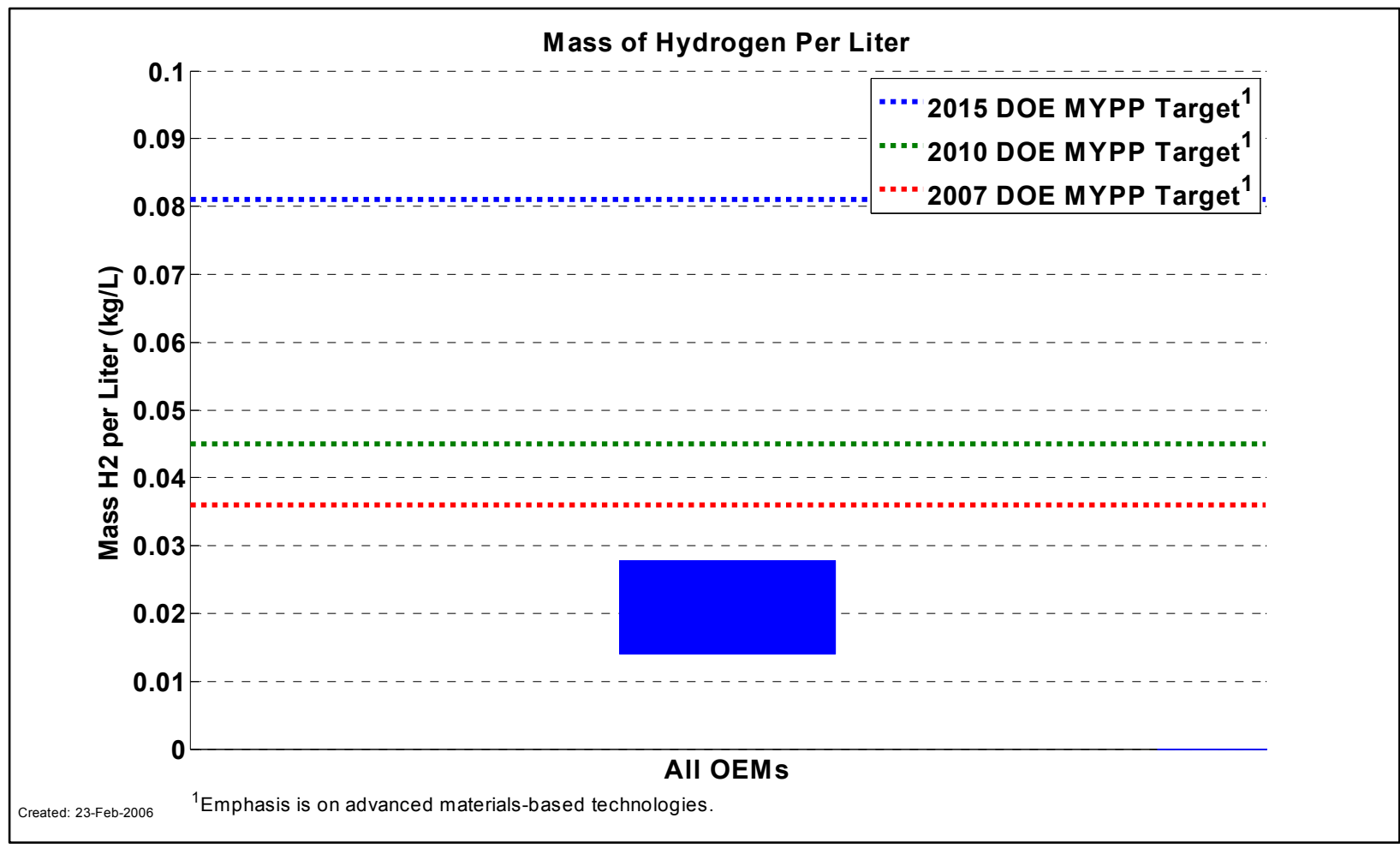

Figure 29: Compressed and Liquid Hydrogen Tank Volumetric Capacity 


\section{Cumulative Hydrogen Produced or Dispensed}

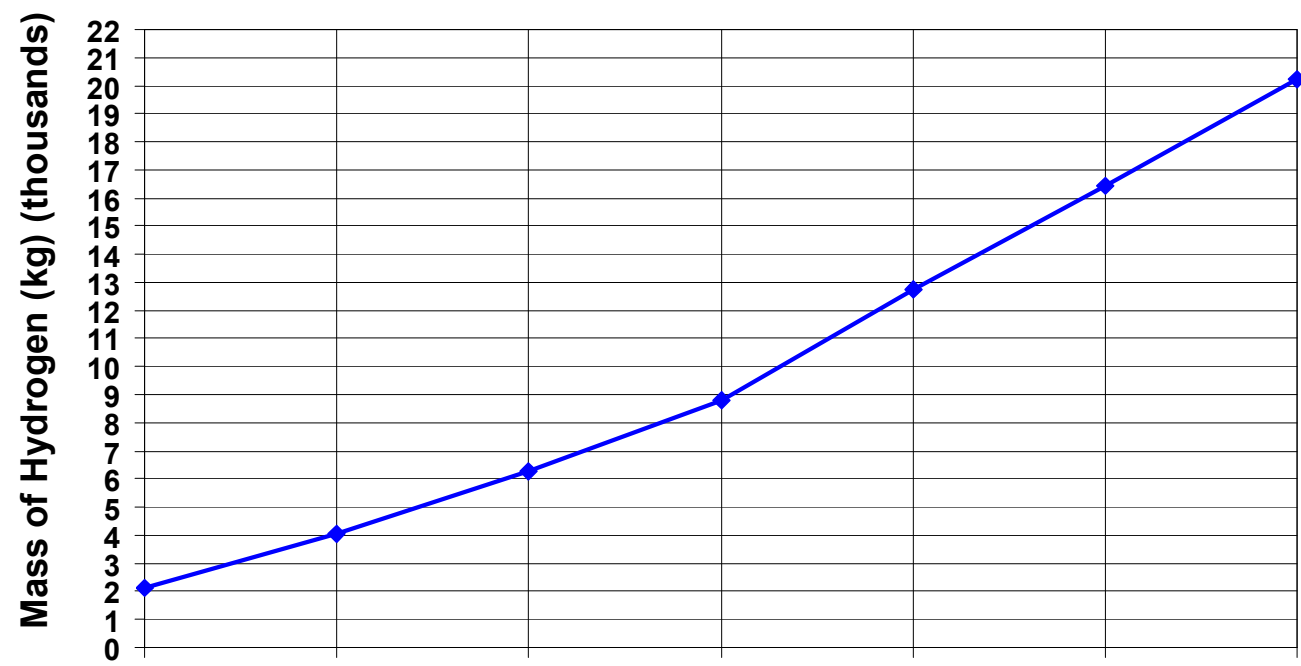

Q2 2005 Q3 2005 Q4 2005 Q1 2006 Q2 2006 Q3 $2006 \quad$ Q4 2006

Calendar Quarter

Figure 30: Cumulative Hydrogen Produced or Dispensed

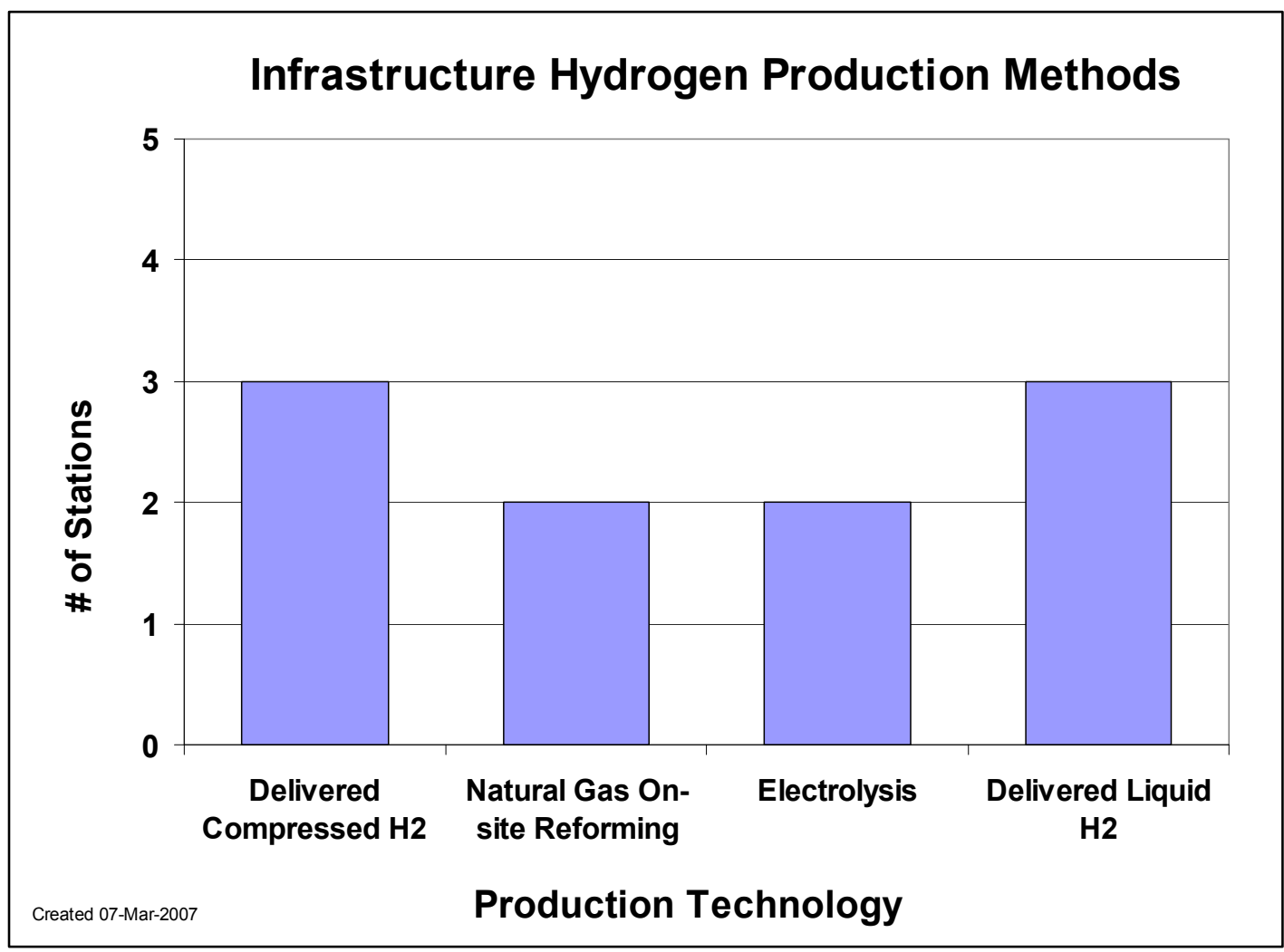

Figure 31: Number and Types of Hydrogen Stations Being Demonstrated 


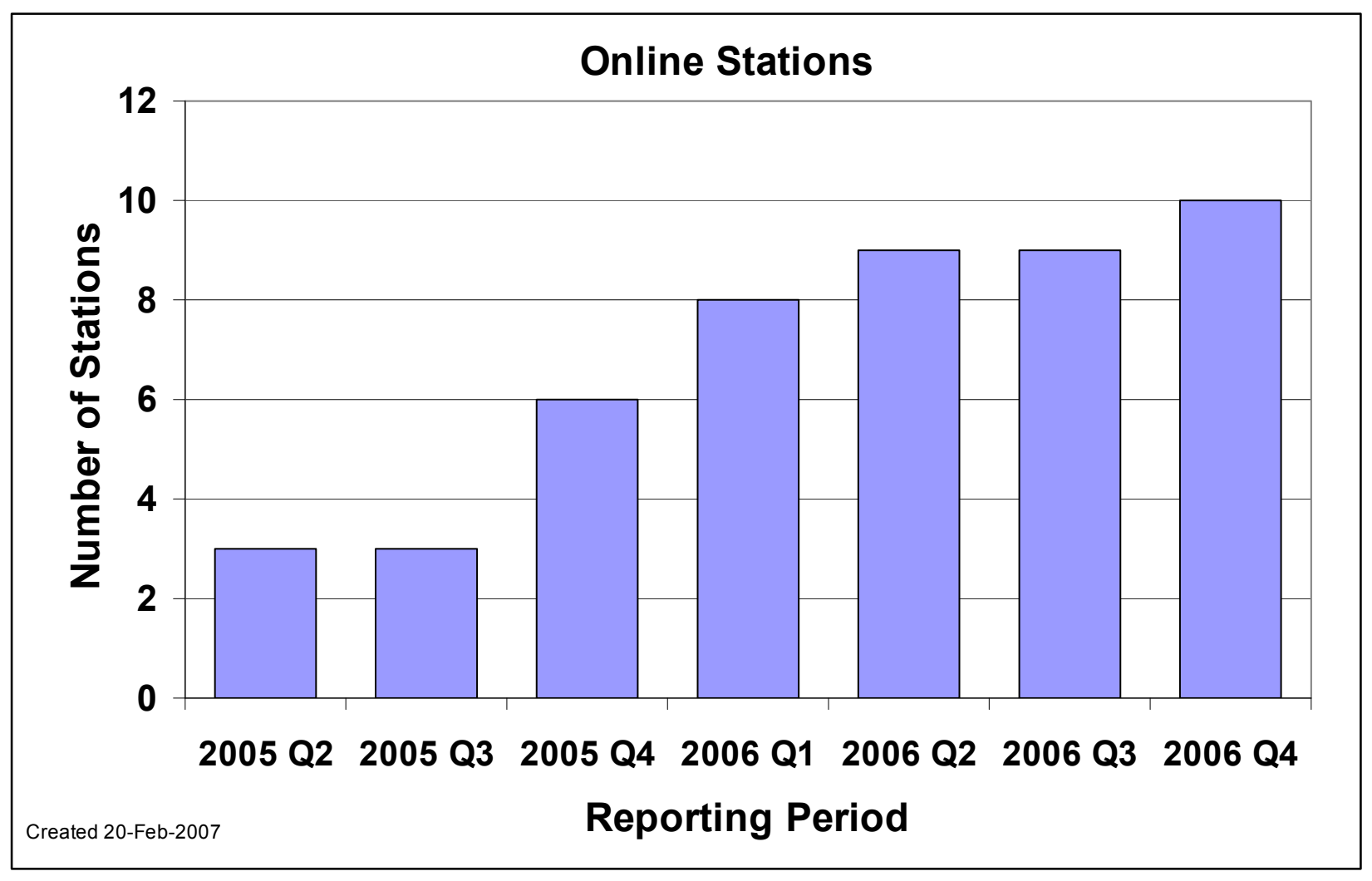

Figure 32: Number of Stations Online by Quarter 


\section{REPORT DOCUMENTATION PAGE}

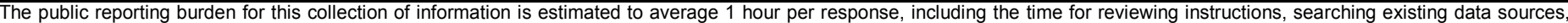

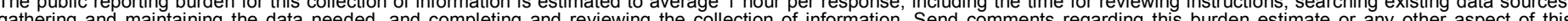

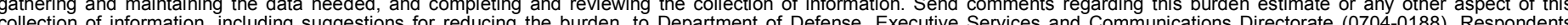

should be aware that notwithstanding any other provision of law, no

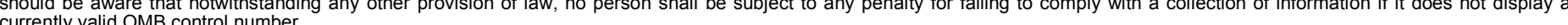

PLEASE DO NOT RETURN YOUR FORM TO THE ABOVE ORGANIZATION.

\begin{tabular}{l|l|l|l} 
1. REPORT DATE $(D D-M M-Y Y Y Y)$ & 2. REPORT TYPE & 3. DATES COVERED (FrOm - TO)
\end{tabular}

July 2007

4. TITLE AND SUBTITLE

Learning Demonstration Interim Progress Report - Summer 2007 5a. CONTRACT NUMBER

DE-AC36-99-G010337

5b. GRANT NUMBER

5c. PROGRAM ELEMENT NUMBER

5d. PROJECT NUMBER

NREL/TP-560-41848

5e. TASK NUMBER

H2708100

5f. WORK UNIT NUMBER
7. PERFORMING ORGANIZATION NAME(S) AND ADDRESS(ES)

National Renewable Energy Laboratory

1617 Cole Blvd.

Golden, CO 80401-3393
8. PERFORMING ORGANIZATION REPORT NUMBER

NREL/TP-560-41848

9. SPONSORING/MONITORING AGENCY NAME(S) AND ADDRESS(ES)

10. SPONSOR/MONITOR'S ACRONYM(S) NREL

11. SPONSORING/MONITORING AGENCY REPORT NUMBER

12. DISTRIBUTION AVAILABILITY STATEMENT

National Technical Information Service

U.S. Department of Commerce

5285 Port Royal Road

Springfield, VA 22161

13. SUPPLEMENTARY NOTES

14. ABSTRACT (Maximum 200 Words)

This report documents the key results to date from the U.S. DOE Controlled Hydrogen Fleet and Infrastructure

Validation and Demonstration project.

15. SUBJECT TERMS

learning demonstration; validation; fleets

\begin{tabular}{l}
\hline \begin{tabular}{l|l|l|}
\hline 16. SECURITY CLASSIFICATION OF: \\
\hline $\begin{array}{l}\text { a. REPORT } \\
\text { Unclassified }\end{array}$ & $\begin{array}{c}\text { b. ABSTRACT } \\
\text { Unclassified }\end{array}$ & $\begin{array}{l}\text { c. THIS PAGE } \\
\text { Unclassified }\end{array}$ \\
& & \\
\hline
\end{tabular}
\end{tabular}

\begin{tabular}{l|l|} 
17. LIMITATION \\
OF ABSTRACT \\
UL
\end{tabular}

19a. NAME OF RESPONSIBLE PERSON

19b. TELEPHONE NUMBER (Include area code) 